Article

\title{
Synthesis, Microtubule-Binding Affinity, and Antiproliferative Activity of New Epothilone Analogs and of an EGFR-Targeted Epothilone-Peptide Conjugate
}

\author{
Fabienne Zdenka Gaugaz ${ }^{1}$, Andrea Chicca ${ }^{2}{ }^{\oplus}$, Mariano Redondo-Horcajo ${ }^{3}{ }^{\circledR}$, Isabel Barasoain ${ }^{3}$, \\ J. Fernando Díaz ${ }^{3}$ (D) and Karl-Heinz Altmann ${ }^{1, *(\mathbb{D})}$ \\ 1 ETH Zürich, Department of Chemistry and Applied Biosciences, Institute of Pharmaceutical Sciences, \\ 8093 Zürich, Switzerland; fabienne.gaugaz@gmx.net \\ 2 Institute of Biochemistry and Molecular Medicine, University of Bern, 3012 Bern, Switzerland; \\ andrea.chicca@ibmm.unibe.ch \\ 3 Centro de Investigaciones Biológicas, Consejo Superior de Investigaciones Científicas, 28040 Madrid, Spain; \\ horcajo@cib.csic.es (M.R.-H.); i.barasoain@cib.csic.es (I.B.); fer@cib.csic.es (J.F.D.) \\ * Correspondence: karl-heinz.altmann@pharma.ethz.ch; Tel.: +41(0)44-633-73-90
}

Received: 18 January 2019; Accepted: 26 February 2019; Published: 5 March 2019

\begin{abstract}
A new simplified, epoxide-free epothilone analog was prepared incorporating an $\mathrm{N}$-(2-hydroxyethyl)-benzimidazole side chain, which binds to microtubules with high affinity and inhibits cancer cell growth in vitro with $\mathrm{nM}$ potency. Building on this scaffold, a disulfide-linked conjugate with the purported EGFR-binding (EGFR, epidermal growth factor receptor) peptide GE11 was then prepared. The conjugate retained significant microtubule-binding affinity, in spite of the size of the peptide attached to the benzimidazole side chain. The antiproliferative activity of the conjugate was significantly lower than for the parent scaffold and, surprisingly, was independent of the EGFR expression status of cells. Our data indicate that the disulfide-based conjugation with the GE11 peptide is not a viable approach for effective tumor-targeting of highly potent epothilones and probably not for other cytotoxics.
\end{abstract}

Keywords: cancer; drug discovery; epothilone; medicinal chemistry; microtubule-stabilizing agents; prodrug; total synthesis; tumor-targeting

\section{Introduction}

Tubulin modulators represent an important class of anticancer drugs that includes microtubule-stabilizing agents (MSA) such as paclitaxel, docetaxel, and ixabepilone as well as microtubule disrupters such as vinblastine and vincristine [1]. However, in spite of their clinical relevance and therapeutic success, drugs acting on the tubulin/microtubule system are still associated with significant side effects, due to the ubiquitous nature of their target protein tubulin [2]. Thus, the specific targeting of tubulin modulators, and cytotoxic agents in general, to tumors, has emerged as an important strategy in anticancer drug discovery and development. The most advanced approach towards the tumor-targeting of cytotoxic agents is their attachment to tumor-specific antibodies, with three antibody-drug conjugates (ADCs) being currently approved for cancer treatment in humans [3,4]; for two of these ADCs, the cytotoxic payload is a microtubule disrupter, i.e., monomethyl auristatin for brentuximab vedotin and the maytansine derivative DM- 1 for trastuzumab emtansine. Alternative targeting moieties are peptides [5] or small molecules that interact specifically with proteins on tumor cell surfaces (e.g., folic acid [6] or synthetic organic molecules $[7,8]$ ). 
When designing tumor-targeted conjugates of cytotoxic agents, two of the most crucial questions relate to the site of the attachment of the linker between the bioactive parent molecule and the targeting moiety and the nature of the linker moiety itself. Numerous linker modalities have been investigated in the literature, including protease/peptidase-cleavable linkers or simple disulfide groups (often in combination with a self-immolative structural element) [9]. Interestingly, the approved ADC trastuzumab emtansine incorporates a non-cleavable linker and the release of the active drug moiety is based on lysosomal degradation of the targeting antibody, leaving behind a construct composed of DM-1, the connector between DM-1 and the antibody, and the lysine reside to which the connector is attached as the pharmacologically active agent. We have recently shown for the first time that this construct does indeed bind to tubulin with similar affinity as the parent compound DM-1 (as its methylsulfanyl derivative) [10].

Epothilones A and B (Epo A and B) (Figure 1) are 16-membered myxobacterial macrolides that exhibit potent microtubule-stabilizing activity $[11,12]$. Both compounds exert strong antiproliferative effects on human cancer cells in vitro [12,13] and in human xenograft models in mice, including cell lines and tumors with taxol resistance [14-16]. The cytotoxic activity of Epo A is similar to that of taxol, whereas Epo B is generally more potent than taxol by at least one order of magnitude, with sub-nanomolar $\mathrm{IC}_{50}$ values for most cell lines [12,13].
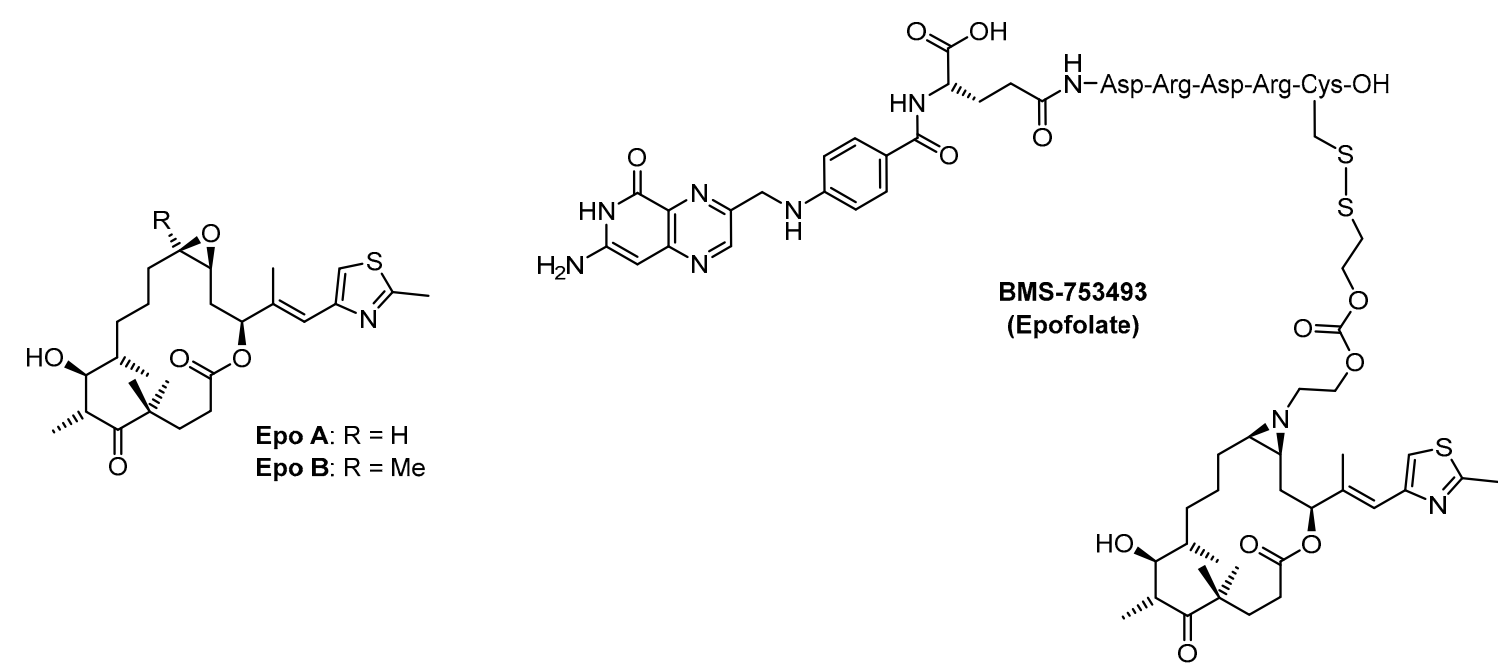

Figure 1. Molecular structures of epothilones A and B and of the tumor-targeted epothilone conjugate BMS-753493 (epofolate).

Epothilones have been the subject of extensive SAR studies and at least eight epothilone-type agents have been advanced to clinical trials in humans in cancer $[17,18]$, including the FDA-approved anticancer drug ixabepilone (the lactam analog of Epo B) [19]; in addition, 12,13-deoxy-Epo B (Epo D) has been investigated in Phase I clinical trials for Alzheimer's disease [20]. While development of most of these compounds has been terminated (including the development of Epo D for Alzheimer's disease), an analog termed utidelone (or UTD1) is currently undergoing Phase III clinical studies for breast cancer treatment in combination with capecitabine [21]. (Very surprisingly (and, in fact, irritatingly), several publications on this compound have appeared in the peer-reviewed literature, without its structure being revealed in any of these papers) [22]. Known attempts at the development of tumor-targeted derivatives of epothilones so far have been limited to the highly elaborate folate conjugate BMS-753493 (epofolate) (Figure 1) [23], where linker cleavage involves intracellular disulfide reduction followed by intramolecular ester cleavage to produce an $\mathrm{N}$-(2-hydroxyethyl) derivative of aziridine-Epo A as the cytotoxic effector molecule.

In this paper, we report a different approach towards the design of epothilone-based tumor-targeted conjugates that is based on the benzimidazole-containing, structurally simplified 
cyclopropyl-trans-epothilone A analog 1 (Figure 2). We have previously shown that the related epothilone analog 3 (Figure 2) shows similar antiproliferative activity as Epo B [24]; at the same time, the presence of the larger 2-hydroxyethyl substituent on the benzimidazole moiety was found to be well tolerated for a corresponding cyclopropyl-Epo B derivative [25]. Lastly, the replacement of the epoxide moiety in natural epothilones by a cyclopropane ring is expected to lead to enhanced metabolic stability.
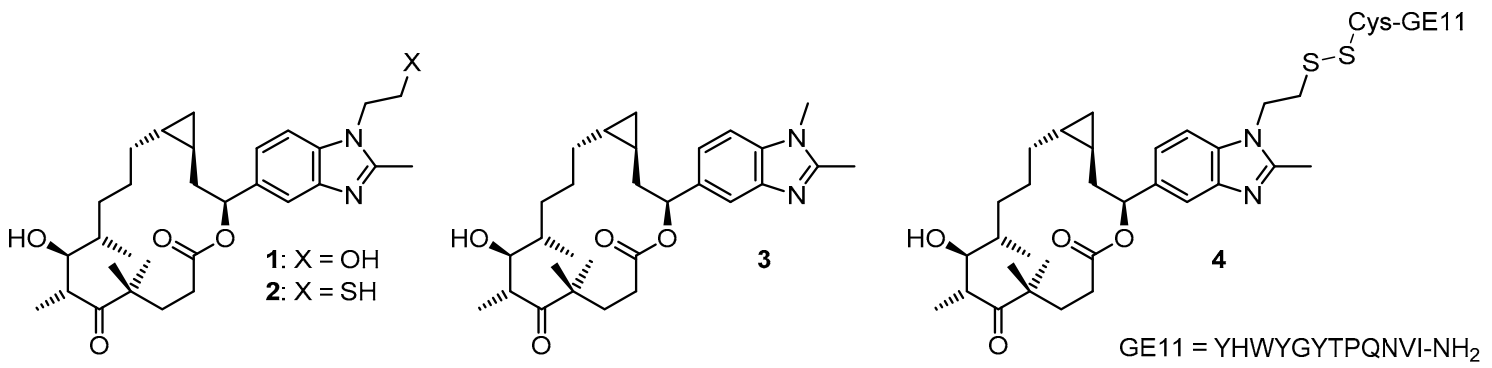

Figure 2. Molecular structures of epothilone analogs 1-3 and of the tumor-targeted epothilone peptide conjugate 4 .

In the actual tumor-targeted conjugate 4 , the thiol analog of 1 (i.e., 2 ) is connected to the side chain of a Cys residue added to the $\mathrm{N}$-terminus of the epidermal growth factor receptor (EGFR)-binding peptide GE11 [26]. Reductive disulfide cleavage of this conjugate, thus, would directly lead to the cytotoxic effector molecule without the need for a subsequent immolative step (as in BMS-753493).

The EGFR (HER1, ErbB1) is a $170 \mathrm{kDa}$ transmembrane glycoprotein with an intracellular tyrosine kinase effector domain [27]. Enhanced EGFR signaling is associated with increased proliferation, differentiation, angiogenesis, invasion and metastasis and overexpression or mutation of EGFR is characteristic of a variety of human tumors [28]. Importantly in the context of this work, the EGFR is the targeted cell surface element for one of the marketed ADCs (trastuzumab emtansine). GE11 is a 12-amino acid residue peptide of the sequence YHWYGYTPQNVI, which has been reported to bind to EGFR with high affinity and specificity $\left(\mathrm{K}_{\mathrm{d}} 22 \mathrm{nM}\right)$, to be internalized preferentially into cells with high EGFR expression levels and to accumulate in EGFR-overexpressing tumor xenografts after i.v. administration in vivo [26]. GE11 has been investigated as a tumor-targeting device, e.g., in liposomes [29], nanoparticles [30], or polymeric prodrugs [31], but also for receptor imaging purposes [32].

\section{Results and Discussion}

\subsection{Chemistry}

The synthesis of both epothilone analog 1 as well as GE11-conjuagte 4 proceeded through the protected macrolactone $\mathbf{1 2}$ as a key precursor; as outlined in Scheme 1, the latter was obtained from the known olefin 5 [25] as an advanced intermediate. Cross metathesis of 5 (83\% ee) with cis-buten-1,4-diol gave allylic alcohol 6 as an inseparable ca. 3:1 mixture of $E / Z$ isomers, which was submitted as such to Charette cyclopropanation [33]. The cyclopropanation reaction furnished a mixture of products 7 that could not be separated. According to ${ }^{1} \mathrm{H}-\mathrm{NMR}$, two major isomers were present in a ca. 9:1 ratio, but it was not determined if these isomers were distinguished by the configuration of the hydroxyl-bearing stereocenter (as a consequence of the imperfect stereochemical purity of olefin 5) or by the stereochemistry of the cyclopropane moiety. Oxidation of 7 with Dess-Martin periodinane furnished aldehyde 8 as a mixture of three detectable isomers in a 1:0.14:0.03 ratio (based on the aldehyde signal in the ${ }^{1} \mathrm{H}-\mathrm{NMR}$ spectrum), which again proved to be inseparable. Aldehyde 8 was obtained in a $58 \%$ overall yield for the three-step sequence from olefin 5 . 


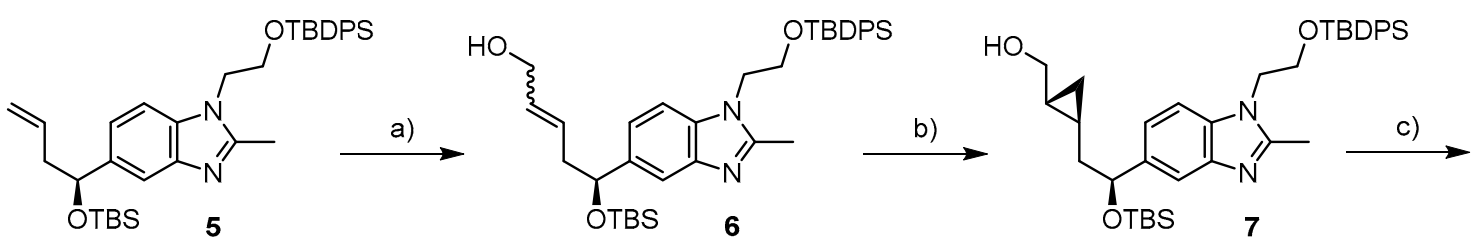

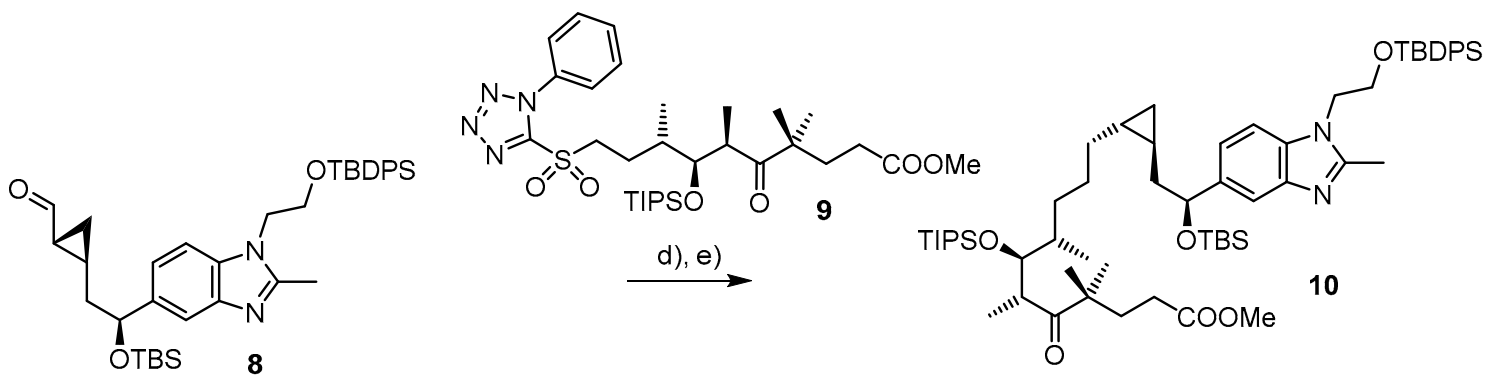

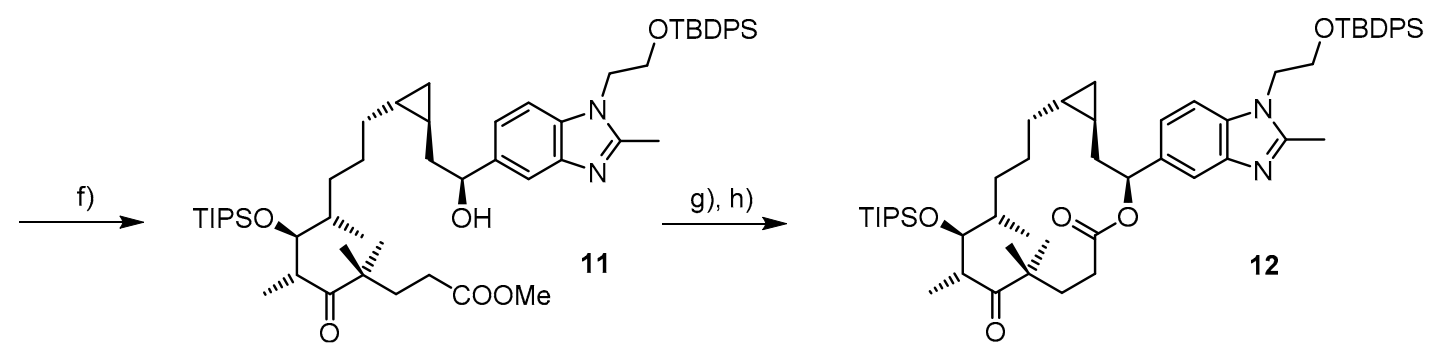

Scheme 1. (a) cis-But-2-ene-1,4-diol, Hoveyda-Grubbs II (20 mol \%), DCM, rt, 22 h, $80 \%, E / Z$ ca. $3: 1 . \quad$ (b) i. $\mathrm{Et}_{2} \mathrm{Zn}, \mathrm{CH}_{2} \mathrm{I}_{2}, \mathrm{DCM},-10{ }^{\circ} \mathrm{C}, 15 \mathrm{~min} ;$ ii. 6, (4S,5S)-2-butyl- $N, N, N^{\prime}, N^{\prime}$-tetramethyl-1,3,2-dioxaborolane-4,5-dicarboxamide, DCM, $0{ }^{\circ} \mathrm{C}$ to $\mathrm{rt}, 2 \mathrm{~h}$, $78 \%$. (c) DMP, DCM, rt, 5 h, 92\%. (d) LiHMDS, THF, $-78{ }^{\circ} \mathrm{C}$ to rt, $2 \mathrm{~h}, 72 \%$. (e) NBSH, TEA, DCM, rt, 16 h, 98\%. (f) CSA, DCM/MeOH 1:1, rt, 16 h, quant. (g) LiOH, t-BuOH/ $\mathrm{H}_{2} \mathrm{O}$ 4:1, rt, 2.5 h, 98\%. (h) 2,4,6 trichlorobenzoyl chloride, DMAP, TEA, toluene, rt, 2 h, 51\%. Abbreviations: DCM: dichloromethane; DMP: Dess-Martin periodinane; CSA: camphorsulfonic acid; DMAP: 4-dimethylaminopyridine; LiHMDS: lithium hexamethyldisilazane; NBSH: $o$-nitrobenzenesulfonylhydrazide; TEA: triethylamine; THF: tetrahydrofuran.

The elaboration of aldehyde 8 into the epothilone macrocyclic framework in a first step entailed Julia-Kocienski olefination with sulfone 9 (Scheme 1) [34]. The reaction was best carried out under Barbier conditions in the presence of two equivalents of LiHMDS, which furnished the desired olefin in a $72 \%$ yield with ca. $2 / 1$ selectivity (based on ${ }^{1} \mathrm{H}-\mathrm{NMR}$ ). The low selectivity of the olefination reaction was inconsequential, as the double bond was reduced in the next step with diimide to provide the fully protected seco ester 10 in quantitative yield. Either 2,4,6-triisopropylbenzenesulfonylhydrazide (TPSH) [35] or o-nitrobenzenesulfonylhydrazide (NBSH, as a cheaper alternative) [36] could be employed as a diimide source, with both methods delivering 10 in excellent yields. Selective cleavage of the benzylic silyl-ether with CSA in DCM/MeOH 1:1 then furnished alcohol 11 in quantitative yield. (Careful inspection of the NMR spectra of $\mathbf{1 0}$ and $\mathbf{1 1}$ suggested the presence of at least one minor isomer in both cases, whose content was difficult to quantify, however). Saponification of methyl ester $\mathbf{1 1}$ gave a crude acid that was directly submitted to Yamaguchi macrolactonization [37], to give the fully protected macrolactone $\mathbf{1 2}$ in 51\% yield after purification by preparative RP-HPLC. Ca. $500 \mathrm{mg}$ of this key intermediate were prepared in a purity that was sufficient for subsequent manipulations, thus highlighting the practicability of the process developed.

As illustrated in Scheme 2, global deprotection of $\mathbf{1 2}$ with HF-pyridine gave trans-cyclopropyl epothilone 1 in 33\% yield after purification by preparative RP-HPLC. Alternatively, 12 could be selectively deprotected at the primary hydroxyl group with TASF (tris(dimethylamino)sulfonium 
difluoromethylsilicate) [38] to give the partially protected macrolactone $\mathbf{1 3}$ in quantitative yield. Mitsunobu reaction with thioacetic acid as the nucleophile then gave a thioester derivative from which the O-TIPS (triisopropylsilylether) protecting group was removed with HF.pyridine, to provide thioacetate 14 . The latter could be directly converted into the activated mixed disulfide $\mathbf{1 5}$ by reaction with 2,2'-dipyridyl disulfide under slightly basic conditions. Reaction of $\mathbf{1 5}$ with CysGE11 then provided the desired epothilone-GE11 conjugate 4.

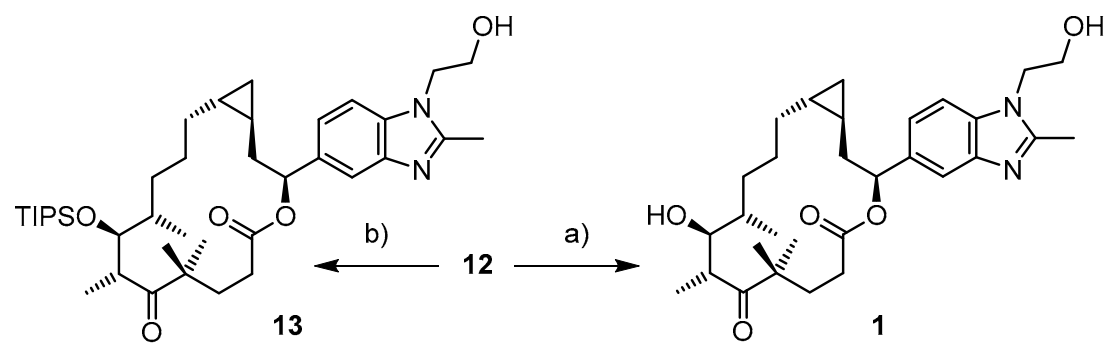

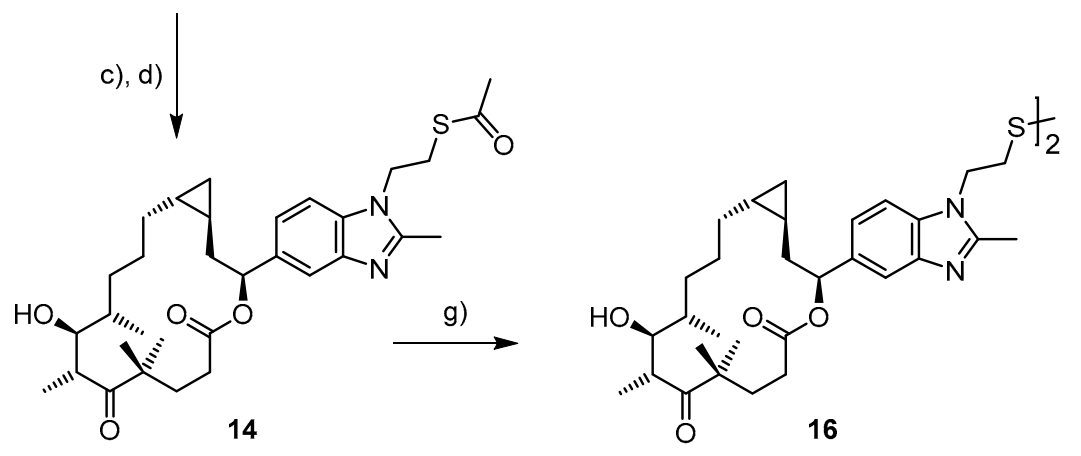

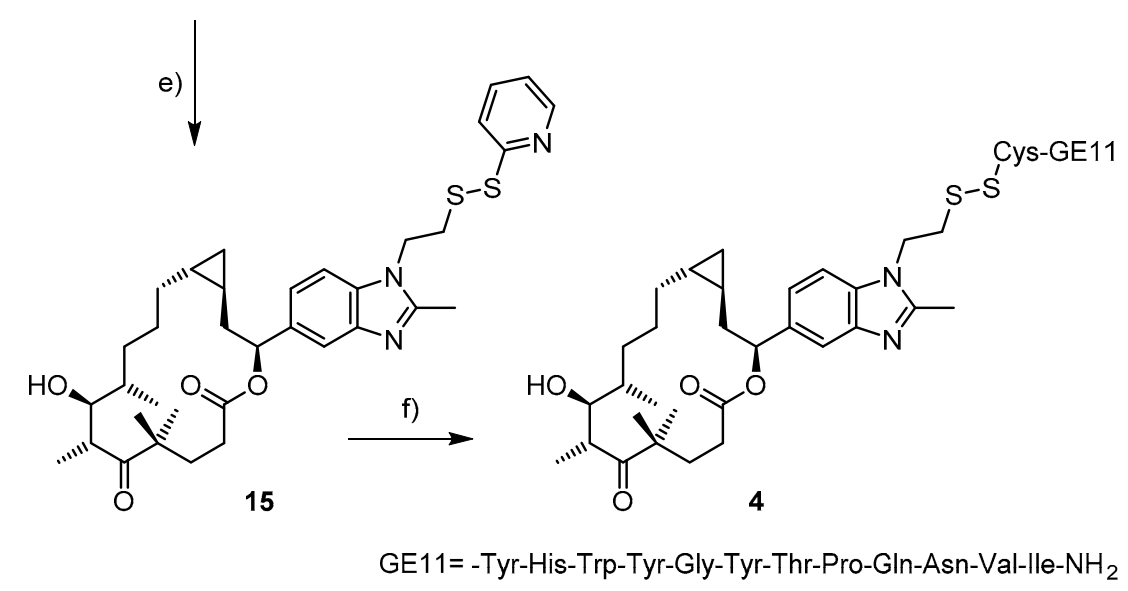

Scheme 2. (a) HF.py, MeCN, rt, 16 h, 33\% after HPLC. (b) TASF, DMF, $0{ }^{\circ} \mathrm{C}, 2 \mathrm{~h}$, quant. (c) $\mathrm{PPh}_{3}$, $\mathrm{DEAD}, \mathrm{AcSH}, \mathrm{Et}_{2} \mathrm{O}, 0{ }^{\circ} \mathrm{C}$ to rt, $3.5 \mathrm{~h}$. (d) HF.py, pyridine, $\mathrm{MeCN}, \mathrm{rt}, 53 \mathrm{~h}, 87 \%$ (2 steps). (e) 2,2'-dipyridyl disulfide, $\mathrm{K}_{2} \mathrm{CO}_{3}, \mathrm{MeOH}, \mathrm{rt}, 30 \mathrm{~min}, 79 \%$. (f) CysGE11, MeOH, rt, $2 \mathrm{~h}, 15 \%$ after HPLC. (g) $\mathrm{K}_{2} \mathrm{CO}_{3}, \mathrm{MeOH}, \mathrm{rt}, 20 \mathrm{~min}, 24 \%$ after RP-HPLC. Abbreviations: TASF: tris(dimethylamino)sulfonium difluoromethylsilicate; DMF: dimethyl formamide; DEAD: diethyl azodicarboxylate.

While the thioester moiety of 14 could be readily cleaved with $\mathrm{K}_{2} \mathrm{CO}_{3} / \mathrm{MeOH}$, the resulting free thiol 2 could not be isolated as a pure material. Disulfide formation was already observed between elution of the material from the HPLC column and lyophilization of the sample. Only disulfide $\mathbf{1 6}$ could be isolated and characterized. 


\subsection{Biological Assessment}

In order to provide a rational framework for the biological assessment of the epothilone peptide conjugate 4, EGFR was quantified in cell lines that were to be used for those experiments, i.e., A431 epidermoid squamous cell carcinoma cells, SW480 colorectal adenocarcinoma cells, and HEK293 embryonic kidney cells. A431 cells have been reported to highly overexpress EGFR [39]; consistent overexpression of EGFR has also been described for SW480 cells [40]. In contrast, HEK293 cells were previously found not to express EGFR [39]. Expression levels of EGFR were assessed by the treatment of cells with cetuximab followed by FACS-based quantification of cetuximab with an Alexa Fluor 647 goat anti-human antibody. In line with the existing literature, EGFR expression levels were found to be highest in A431 cells, followed by SW480 cells. HEK293 cells gave fluorescence intensities at the level of the isotype control (Figure S1). Therefore, 4 would have been expected to display strongest cytotoxicity against A431 and SW480 cells, while HEK293 cells should have been largely insensitive to the action of the conjugate. As will be discussed below, the experimental results did not conform to these predictions.

The stability of the epothilone-GE11 conjugate 4 in complete cell culture medium was evaluated under conditions resembling those encountered in the cytotoxicity assays. Thus, an $8.6 \mu \mathrm{M}$ solution of 4 in RPMI with $10 \%$ FBS was incubated for 3 days at $37^{\circ} \mathrm{C}$ and subsequently analyzed by RP-HPLC. Only minor degradation of $4(<10 \%)$ was observed under these conditions (data not shown).

The reductive cleavage of conjugate 4 was analyzed under conditions mimicking those found in the endosome and the cytoplasm of cancer cells [41]. Endosome-like conditions were assumed to be reproduced by a $10 \mathrm{mM}$ solution of glutathione (GSH) in acetate and phosphate buffer $\mathrm{pH} 4.9$; cytoplasm-like conditions entailed $10 \mathrm{mM} \mathrm{GSH}$ in phosphate buffer $\mathrm{pH}$ 7.4. Under both conditions, rapid disappearance of 4 was observed with apparent first order kinetics (Figure 3).

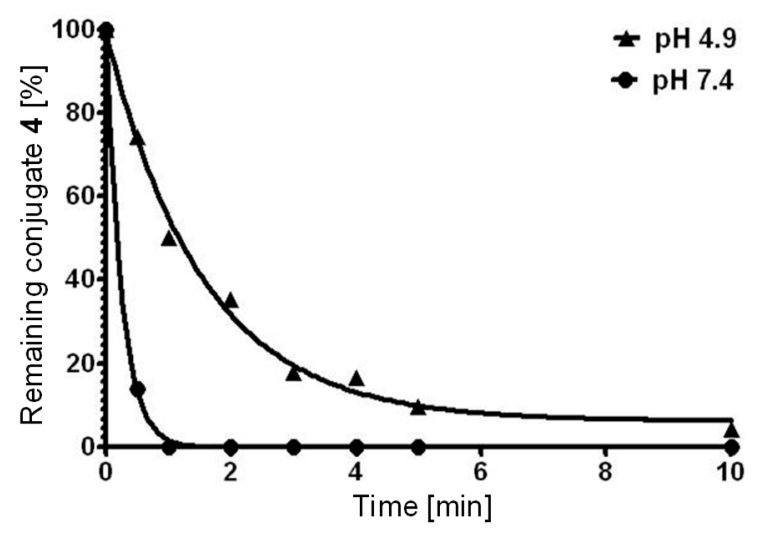

Figure 3. Kinetics of glutathione (GSH)-mediated reduction of epothilone-peptide conjugate 4 (173 $\mu \mathrm{M}$ 4, $10 \mathrm{mM} \mathrm{GSH}, \mathrm{pH} 4.9$ (endosome-like conditions), triangles, or pH 7.4 (cytoplasm-like conditions), circles). Conjugate 4 was added to the respective GSH solutions as a solution in phosphate buffer $\mathrm{pH}$ 7.4 at room temperature, to reach a total concentration of $173 \mu \mathrm{M}$. Samples were quenched at different time points with $10 \%$ metaphosphoric acid and analyzed by RP-HPLC. The peak areas for 4 in the RP-HPLC chromatograms were normalized against the peak area of a $200 \mu \mathrm{M}$ solution of 4 in the corresponding GSH-free buffers.

The half-life of 4 was 1.1 min under endosome-like conditions, while no residual conjugate was detectable even $1 \mathrm{~min}$ after addition to the glutathione solution under cytoplasm-like conditions (estimated half-life of ca. $0.2 \mathrm{~min}$ ). LC/MS analysis of cleavage solutions showed that the products obtained at both $\mathrm{pH}$ values included the mono- and dimeric CysGE11 peptide, thiol-containing epothilone analog 2, the mixed disulfide of 2 with glutathione, and dimer 16. The mixed disulfide of 2 with glutathione appeared very early in the reaction (Figure S2); it was later transformed into 2 
and 16. The shorter half-life of 4 under cytoplasm-like conditions is in line with the fact that disulfide reduction is $\mathrm{pH}$-dependent and has been shown to be significantly slower at lower $\mathrm{pH}$ [41].

The binding affinity of epothilone analogs 1, 14, and 16 and of targeted conjugate 4 for microtubules was determined as previously described by Díaz and co-workers, using partly cross-linked microtubules and determining the changes in fluorescence anisotropy upon displacement of the fluorescent taxol derivative Flutax-2 [42,43] (Figure S3). Not unexpectedly, the microtubule-binding affinity of the simplified epothilone analog $\mathbf{1}$ even exceeds that of natural Epo A $\left(\mathrm{K}_{\mathrm{b}}\right.$ of $7.85 \times 10^{7} \mathrm{M}^{-1}$ vs. $3.17 \times 10^{7} \mathrm{M}^{-1}$ for Epo A; Table 1); this observation is in line with existing SAR data for other epothilone analogs that are derived from trans-Epo A and/or incorporate a benzimidazole side chain $[24,25,44]$, although analog 1 has not been investigated previously. Compared to $\mathbf{1}$, the $K_{b}$ for thioacetate $\mathbf{1 4}$ is considerably lower ( $>10$-fold), but its microtubule-binding affinity is still comparable to that of other epothilone analogs that have shown nanomolar antiproliferative activity against different cancer cell lines [45]. Intriguingly, analog $\mathbf{1 6}$ and conjugate $\mathbf{4}$ exhibit similar microtubule-binding affinity as thioacetate 14, in spite of the significant enlargement in size of the substituent group on the benzimidazole side chain. Importantly, the targeting peptide CysCE11 showed no relevant microtubule binding.

Table 1. Binding constants of epothilone analogs 1, 14, and 16 and of epothilone-CE11 conjugate 4 for stabilized microtubules ${ }^{1}$.

\begin{tabular}{cc}
\hline Compound & $\mathbf{K}_{\mathbf{b}}\left[\mathbf{1 0}^{\mathbf{6}} \mathbf{M}^{\mathbf{- 1}}\right]$ \\
\hline $\mathbf{1}$ & $78.5 \pm 17.2$ \\
$\mathbf{1 4}$ & $5.4 \pm 0.8$ \\
$\mathbf{1 6}$ & $9.8 \pm 0.3$ \\
$\mathbf{4}$ & $9.3 \pm 0.5$ \\
CysCE11 & $0.05 \pm 0.02$ \\
Epo A & $31.7 \pm 3.1$ \\
Docetaxel & $26.7 \pm 3.3$ \\
\hline
\end{tabular}

${ }^{1}$ Association constant $\mathrm{K}_{\mathrm{b}}$ with glutaraldehyde-stabilized microtubules at $35^{\circ} \mathrm{C}$, determined as described in [42]. Numbers are average values from 3 independent experiments \pm standard deviation.

The antiproliferative activity of the targeted epothilone conjugate 4 was assessed for A431, SW480, and HEK293 cells, in comparison with epothilone analogs 1 and 16. Of the three compounds investigated, conjugate 4 proved to be the least potent by one order of magnitude (Table 2).

Table 2. Antiproliferative activity of epothilone analogs $\mathbf{1}$ and $\mathbf{1 6}$ and of epothilone-CE11 conjugate 4 against human cancer cell lines $\left(\mathrm{IC}_{50}[\mathrm{nM}]\right)^{1}$.

\begin{tabular}{cccc}
\hline Compound & A431 & SW480 & HEK293 \\
\hline $\mathbf{1}$ & $3.32 \pm 0.60$ & $17.56 \pm 3.50$ & $0.87 \pm 0.13$ \\
$\mathbf{1 6}$ & $8.37 \pm 0.81$ & $8.91 \pm 1.26$ & $2.08 \pm 0.53$ \\
$\mathbf{4}$ & $74.74 \pm 6.65$ & $180.8 \pm 25.9$ & $31.09 \pm 6.21$ \\
Epo A & $2.94 \pm 0.30$ & $14.52 \pm 1.09$ & $2.71 \pm 0.62$ \\
\hline
\end{tabular}

${ }^{1}$ Cells were incubated with test compounds for $72 \mathrm{~h}$. A431: epidermoid squamous cell carcinoma cells; SW480: colorectal adenocarcinoma cells; HEK293: embryonic kidney cells. Numbers presented are average values from three independent experiments \pm standard deviation. For experimental details see the Supplementary Materials.

While the lower activity of 4 compared to 1 against A431 and SW480 cells could potentially be rationalized by a lower rate of receptor-mediated uptake vs. uptake by passive diffusion (which is likely to be operative for $\mathbf{1}$ ) and/or the efficiency of formation of $\mathbf{2}$ from 4 in, and its release from, the endosomal compartment, the lack of selectivity between EGFR-expressing A431 and SW480 cells and essentially EGFR-free HEK293 cells is difficult to explain. This finding may point to cleavage of the disulfide bond in the extracellular space, and the passive diffusion of $\mathbf{2}$ into the cells (assuming that passive diffusion of conjugate 4 through the cell membrane followed by intracellular disulfide 
reduction is essentially excluded). Should this indeed be the case, the same mechanism may also underlie the activity of 4 against A431 and SW480 cells, without the involvement of EGFR-mediated endocytosis. In this context, it should be remembered that $10 \%$ disulfide cleavage or less would already account for the observed $\mathrm{IC}_{50}$ values, if one assumes the (elusive) epothilone $\mathbf{2}$ to exhibit similar activity as 1. Extracellular disulfide cleavage as the source of the antiproliferative activity of 4 would thus still be compatible with the stability data obtained for the compound in cell culture medium (vide supra). Preliminary experiments aiming at the quantification of intracellular concentrations of 4,2 , or 16 did not produce any interpretable results.

In a broader context, we note that recycling endosomes, late endosomes, and lysosomes, in contrast to our own basic assumption, had been suggested to provide a reducing, rather than oxidizing environment, even prior to the start of our work on 4 [46]. At the same time, careful inspection of the literature suggests that, while the GE11 peptide does seem to allow selective targeting of EGFR-overexpressing cells by nanoparticles [30] or polymeric prodrugs [31], the selectivity that has been achieved is rather moderate. In line with these observations, the reported $K_{d}$ of $22 \mathrm{nM}$ of GE11 for the EGFR could not be reproduced in subsequent studies by other laboratories. Thus, Levitzki and co-workers determined the $\mathrm{IC}_{50}$ for the displacement of [ $\left.{ }^{125} \mathrm{I}\right]-\mathrm{EGF}$ from the EGFR by GE11 to be $>1 \mathrm{mM}$ (!) (vs. $5.1 \mathrm{nM}$ for EGF) [47]; more recently, Lin and co-workers determined the $\mathrm{K}_{\mathrm{d}}$ of GE11 for the EGFR as $459 \mu \mathrm{M}$ by means of surface plasmon resonance [48]. Similar findings have been reported by Sihver and co-workers in the context of studies on potential GE11-derived PET imaging agents [49]. Thus, in retrospect, neither the choice of the GE11 peptide as an EGFR-targeting moiety nor its combination with a disulfide linker may have been optimal.

The antiproliferative activity of disulfide $\mathbf{1 6}$ is similar to that of analog $\mathbf{1}$, in spite of its $>10$-fold lower microtubule-binding affinity. While microtubule-binding affinity is not necessarily linearly correlated with cell growth inhibition, this finding may point to thiol-containing epothilone analog 2 as the species mainly responsible for the antiproliferative effects of $\mathbf{1 6}$. It is easily conceivable for disulfide $\mathbf{1 6}$ to readily cross the cellular membrane by passive diffusion (the molecular weight of $\mathbf{1 6}$ is $1054 \mathrm{vs.}$., e.g., 856 for taxol, which easily enters cells); immediate reduction in the cytoplasmic compartment would then produce 2 . However, we do not have any experimental data at this point to support this (plausible) mechanistic hypothesis.

\section{Materials and Methods}

\subsection{Chemistry}

All non-aqueous reactions were carried out under anhydrous conditions and under an argon atmosphere unless otherwise noted. $\mathrm{CH}_{2} \mathrm{Cl}_{2}$ was distilled from $\mathrm{CaH} ; \mathrm{THF}, \mathrm{Et}_{2} \mathrm{O}$, benzene, and toluene were distilled from $\mathrm{Na}$ /benzophenone. All other absolute solvents were purchased from Fluka (absolute over molecular sieves). Commercial chemicals were used without further purification, unless otherwise noted.

Solvents for extractions, column chromatography, and thin layer chromatography (TLC) were purchased as commercial grade and distilled prior to use. TLC was performed on Merck TLC aluminum sheets (silica gel 60, F254). Spots were visualized with UV light (254 nm) or through staining with an aqueous solution of phosphomolybdic acid, cerium sulfate, and sulfuric acid (CPS). Chromatographic purification of products was performed by flash chromatography (FC) using Fluka silica gel 60 for preparative column chromatography (particle size 40-63 $\mu \mathrm{m}$ ). Organic solutions were concentrated by rotary evaporation at $40{ }^{\circ} \mathrm{C}$ and approximately $20 \mathrm{mbar}$. The compounds were further dried under high vacuum (0.01-0.001 mbar). Yields refer to compounds isolated after FC, unless otherwise specified. NMR spectra were recorded on a Bruker AV-400 $400 \mathrm{MHz}$ or a Bruker AV-500 $500 \mathrm{MHz}$ NMR spectrometer (Bruker Biospin AG, Fällanden, Switzerland) at $298 \mathrm{~K}$. NMR spectra are referenced relative to the residual hydrogen signal of the deuterated solvent $\left({ }^{1} \mathrm{H} 7.26 \mathrm{ppm},{ }^{13} \mathrm{C} 77.0\right.$ ppm for $\mathrm{CDCl}_{3}$ ). All ${ }^{13} \mathrm{C}$ spectra were measured with complete proton decoupling. For inseparable 
diastereomeric mixtures, only signals of the major diastereomer are reported. Spin multiplicities are reported as follows: $\mathrm{s}=$ singlet, $\mathrm{d}=$ doublet, $\mathrm{t}=$ triplet, $\mathrm{q}=$ quartet, quint $=$ quintet, sext $=$ sextet, $\mathrm{m}=$ multiplet, $\mathrm{mc}=$ centered multiplet, $\mathrm{br}=$ broad signal; $\mathrm{J}=$ coupling constant in $\mathrm{Hz}$. Infrared spectra (IR) were recorded on a Jasco FT/IR-6200 instrument. Positions of absorption bands are given in wavenumbers $\left[\mathrm{cm}^{-1}\right]$. Optical rotations were measured on a Jasco P-1020 polarimeter and are reported as follows: $[\alpha]_{D}^{24}$ : concentration $(\mathrm{g} / 100 \mathrm{~mL})$ and solvent. High resolution mass spectra (HRMS) were recorded by the ETH Zürich MS service on a Varian IonSpec Ultima (ESI) or a Waters Micromass Autospec Ultima spectrometer (EI). RP-HPLC was carried out on a Merck Hitachi device (column oven L-2350, diode array detector L-2450, autosampler L-2200, pump L-2130) using a Waters Symmetry C18 column, $3.5 \mu \mathrm{m}, 4.6 \times 100 \mathrm{~mm}$, at a flow rate of $1 \mathrm{~mL} / \mathrm{min}$ for analytical purposes; a Waters Symmetry C18 column, $5 \mu \mathrm{m}, 7.8 \times 100 \mathrm{~mm}$, at a flow rate of $2 \mathrm{~mL} / \mathrm{min}$ was employed for semi-preparative applications. The column temperature for analytical and semi-preparative applications was $40^{\circ} \mathrm{C}$. Preparative RP-HPLC was carried out on a Gilson device (Gilson (Schweiz) AG, Mettmenstetten, Switzerland) with a Waters Symmetry C18 column (Waters AG, Baden-Dättwil, Switzerland), $5 \mu \mathrm{m}, 19$ $\times 100 \mathrm{~mm}$, at a flow rate of $25 \mathrm{~mL} / \mathrm{min}$ at room temperature. Peaks were detected at 280, 254, or 220 $\mathrm{nm}$. The Cys-GE11 peptide was custom-made by Biosyntan GmbH (Berlin, Germany).

\section{(S,E)-5-((tert-Butyldimethylsilyl)oxy)-5-(1-(2-((tert-butyldiphenylsilyl)oxy)ethyl)-2-methyl -1H-benzo[d]imidazol-5-yl)pent-2-en-1-ol (6)}

A solution of Hoveyda-Grubbs II catalyst $(104.6 \mathrm{mg}, 0.167 \mathrm{mmol})$ in DCM $(0.2 \mathrm{~mL})$ was added to a solution of olefin 5 (500 mg, $0.835 \mathrm{mmol})$ and cis-2-butene-1,4 diol $(206 \mu \mathrm{L}, 2.504 \mathrm{mmol})$ in DCM $(6 \mathrm{~mL})$ at rt. The solution was stirred for $22 \mathrm{~h}$ at rt. It was then concentrated in vacuo and purified by FC (EtOAc/MeOH 100:1) to yield $420.2 \mathrm{mg}$ of 6 as a ca. 3/1 mixture of $E / Z$ isomers.

$R_{\mathrm{f}}=0.31(\mathrm{EtOAc} / \mathrm{MeOH} 20: 1) .[\alpha]_{D}^{20}=-16.8\left(\mathrm{c}=1.1 \mathrm{in} \mathrm{CHCl}_{3}\right) .{ }^{1} \mathrm{H} \mathrm{NMR}\left(400 \mathrm{MHz}, \mathrm{CDCl}_{3}\right):$ $\delta=7.60(1 \mathrm{H}, \mathrm{s}), 7.24-7.43(10 \mathrm{H}, \mathrm{m}), 7.13(1 \mathrm{H}, \mathrm{dd}, J=1.43,8.30 \mathrm{~Hz}), 7.05(1 \mathrm{H}, \mathrm{d}, J=8.30 \mathrm{~Hz}), 5.65$ $(2 \mathrm{H}, \mathrm{m}), 4.79(1 \mathrm{H}, \mathrm{dd}, J=5.41,6.95 \mathrm{~Hz}), 4.22(2 \mathrm{H}, \mathrm{t}, J=5.59 \mathrm{~Hz}), 4.04(2 \mathrm{H}, \mathrm{d}, J=4.68 \mathrm{~Hz}), 3.90(2 \mathrm{H}, \mathrm{t}$, $J=5.59 \mathrm{~Hz}), 2.54(3 \mathrm{H}, \mathrm{s}), 2.37-2.65(2 \mathrm{H}, \mathrm{m}), 0.93(9 \mathrm{H}, \mathrm{s}), 0.88(9 \mathrm{H}, \mathrm{s}), 0.02(3 \mathrm{H}, \mathrm{s}),-0.14 \mathrm{ppm}(3 \mathrm{H}, \mathrm{s}) .{ }^{13} \mathrm{C}$ NMR $\left(100 \mathrm{MHz}, \mathrm{CDCl}_{3}\right): \delta=152.30,142.38,139.24,135.51,134.53,132.63,131.64,129.95,129.72,127.90$, $120.25,116.37,108.97,75.43,63.77,62.10,45.88,44.51,26.74,26.00,19.02,18.39,14.09,-4.40,-4.76$. IR: $v=3245,2953,2929,2857,2357,1520,1471,1429,1404,1360,1254,1110,1085,1007,940$ 835, 776, 739, $702 \mathrm{~cm}^{-1}$. HRMS (ESI): $\mathrm{m} / z$ calcd for $\mathrm{C}_{37} \mathrm{H}_{52} \mathrm{~N}_{2} \mathrm{O}_{3} \mathrm{Si}_{2}+\mathrm{H}^{+}$: $629.3589\left[M+\mathrm{H}^{+}\right]$; found 629.3589.

$((1 R, 2 S)-2-((S)-2-(($ tert-Butyldimethylsilyl)oxy)-2-(1-(2-((tert-butyldiphenylsilyl)oxy)ethyl)-2 -methyl-1H-benzo[d]imidazol-5-yl)ethyl) cyclopropyl)methanol (7)

Diiodomethane $(0.16 \mathrm{~mL}, 2 \mathrm{mmol})$ was slowly added to a solution of diethyl zinc (1 $\mathrm{M}$ in hexane, $1 \mathrm{~mL}, 1 \mathrm{mmol})$ in DCM $(1 \mathrm{~mL})$ at $-10^{\circ} \mathrm{C}$ and the solution was stirred for $15 \mathrm{~min}$. (Note the section about EXPLOSIONS in [33]). A preformed solution of allylic alcohol 6 (97 mg, $0.154 \mathrm{mmol}$ ) and (4S,5S)-2-butyl- $N, N, N^{\prime}, N^{\prime}$-tetramethyl-1,3,2-dioxaborolane-4,5-dicarboxamide ( $97 \mu \mathrm{L}, 0.386 \mathrm{mmol}$ ) in DCM $(3 \mathrm{~mL})$ was added at $0{ }^{\circ} \mathrm{C}$. The solution was stirred for $2 \mathrm{~h}$ at rt. It was then washed with $1 \mathrm{M} \mathrm{HCl}$, and the aqueous phase was re-extracted with DCM. The organic layers were transferred to an Erlenmeyer flask, $2 \mathrm{M} \mathrm{NaOH}$ and $\mathrm{H}_{2} \mathrm{O}_{2}, 30 \%, 6: 1$, were added in one portion, and the mixture was vigorously stirred for $5 \mathrm{~min}$. The organic layer was then successively washed with $1 \mathrm{M} \mathrm{HCl}$ and sat. aq. $\mathrm{Na}_{2} \mathrm{SO}_{3}$, dried over $\mathrm{MgSO}_{4}$ and concentrated in vacuo. Purification of the residue by $\mathrm{FC}$ (EtOAc/MeOH 100:1) yielded $77.7 \mathrm{mg}$ of cyclopropane 7 as a mixture of at least two isomers (see text).

$R_{\mathrm{f}}=0.39$ (EtOAc/MeOH 95:5). $[\alpha]_{D}^{20}=-21.1\left(\mathrm{c}=1.1\right.$ in $\left.\mathrm{CHCl}_{3}\right) .{ }^{1} \mathrm{H} \mathrm{NMR}\left(400 \mathrm{MHz}, \mathrm{CDCl}_{3}\right):$ $\delta=7.63(1 \mathrm{H}, \mathrm{s}), 7.24-7.44(10 \mathrm{H}, \mathrm{m}), 7.14(1 \mathrm{H}, \mathrm{dd}, J=1.39,8.28 \mathrm{~Hz}), 7.05(1 \mathrm{H}, \mathrm{d}, J=8.28 \mathrm{~Hz}), 4.84(1 \mathrm{H}$, $\mathrm{t}, J=6.17 \mathrm{~Hz}), 4.22(2 \mathrm{H}, \mathrm{t}, J=5.68 \mathrm{~Hz}), 3.89(2 \mathrm{H}, \mathrm{t}, J=5.68 \mathrm{~Hz}), 3.37(2 \mathrm{H}, \mathrm{m}), 2.54(3 \mathrm{H}, \mathrm{s}), 1.51-1.81$ $(2 \mathrm{H}, \mathrm{m}), 0.93(9 \mathrm{H}, \mathrm{s}), 0.89(9 \mathrm{H}, \mathrm{s}), 0.79(1 \mathrm{H}, \mathrm{m}), 0.65(1 \mathrm{H}, \mathrm{m}), 0.30(2 \mathrm{H}, \mathrm{m}), 0.03(3 \mathrm{H}, \mathrm{s}),-0.12,(3 \mathrm{H}, \mathrm{s})$. ${ }^{13} \mathrm{C}$ NMR $\left(100 \mathrm{MHz}, \mathrm{CDCl}_{3}\right): \delta=152.28,142.41,139.64,135.53,134.49,132.66,129.96,127.91,120.31$, $116.41,108.94,75.49,67.13,62.13,45.90,45.56,26.75,26.05,21.52,19.04,18.39,14.10,13.92,9.81,-4.40$, 
-4.78 ppm; IR: $v=3266,2953,2929,2857,1520,1471,1429,1403,1360,1253,1111,1086,939,836,776$, $739,703 \mathrm{~cm}^{-1}$. HRMS (ESI): $\mathrm{m} / z$ calcd for $\mathrm{C}_{38} \mathrm{H}_{54} \mathrm{~N}_{2} \mathrm{O}_{3} \mathrm{Si}_{2}+\mathrm{H}^{+}: 643.3746\left[M+\mathrm{H}^{+}\right]$; found 643.3744 .

(1R,2S)-2-((S)-2-((tert-Butyldimethylsilyl)oxy)-2-(1-(2-((tert-butyldiphenylsilyl)oxy)ethyl)-2 -methyl-1H-benzo[d]imidazol-5-yl)ethyl) cyclopropanecarbaldehyde (8)

DMP (19.8 mg, $0.047 \mathrm{mmol})$ in DCM $(1 \mathrm{~mL})$ was slowly added to a solution of alcohol 7 (30 mg, $0.047 \mathrm{mmol})$ in DCM $(1 \mathrm{~mL})$ and the solution was stirred for $5 \mathrm{~h}$ at rt. More DMP (10 mg, $0.024 \mathrm{mmol})$ in DCM $(1 \mathrm{~mL})$ was added at this point and stirring was continued for $1 \mathrm{~h}$. The reaction mixture was evaporated and the crude residue was directly purified by FC (EtOAc/MeOH 100:1), to yiel $27.4 \mathrm{mg}$ aldehyde $8(92 \%)$ as a mixture of 3 isomers in a ratio of 1: 0.14: 0.03 .

$R_{\mathrm{f}}=0.73(\mathrm{EtOAc} / \mathrm{MeOH} 95: 5) .[\alpha]_{D}^{20}=-28.5\left(\mathrm{c}=0.4\right.$ in $\left.\mathrm{CHCl}_{3}\right) .{ }^{1} \mathrm{H} \mathrm{NMR}\left(400 \mathrm{MHz}, \mathrm{CDCl}_{3}\right):$ $\delta=8.87(1 \mathrm{H}, \mathrm{d}, J=5.57 \mathrm{~Hz}), 7.61(1 \mathrm{H}, \mathrm{s}), 7.25-7.43(10 \mathrm{H}, \mathrm{m}), 7.11(1 \mathrm{H}, \mathrm{dd}, J=1.31,8.30 \mathrm{~Hz}), 7.06(1 \mathrm{H}, \mathrm{d}$, $J=8.30 \mathrm{~Hz}), 4.85(1 \mathrm{H}, \mathrm{dd}, J=5.02,6.88 \mathrm{~Hz}), 4.23(2 \mathrm{H}, \mathrm{t}, J=5.68 \mathrm{~Hz}), 3.89(2 \mathrm{H}, \mathrm{t}, J=5.68 \mathrm{~Hz}), 2.54(3 \mathrm{H}$, s), $1.93(1 \mathrm{H}, \mathrm{m}), 1.56(2 \mathrm{H}, \mathrm{m}), 1.49(1 \mathrm{H}, \mathrm{m}), 1.20(1 \mathrm{H}, \mathrm{m}), 0.93(9 \mathrm{H}, \mathrm{s}), 0.89(9 \mathrm{H}, \mathrm{s}), 0.85(1 \mathrm{H}, \mathrm{m}), 0.03(3 \mathrm{H}$, s), $-0.15 \mathrm{ppm}(3 \mathrm{H}, \mathrm{s}) .{ }^{13} \mathrm{C}$ NMR $\left(100 \mathrm{MHz}, \mathrm{CDCl}_{3}\right): \delta=201.03,152.42,142.31,139.09,135.53,134.64$, 132.65, 129.99, 127.93, 120.33, 116.18, 109.11, 75.10, 62.14, 45.94, 44.51, 30.54, 26.76, 26.02, 19.39, 19.05, 18.33, 14.42, 14.05, -4.42, -4.82. IR: $v=2953,2928,2856,2352,1708,1521,1471,1463,1429,1402,1361$, $1255,1111,1086,937,836,778,745,736,703 \mathrm{~cm}^{-1}$. HRMS (ESI): $\mathrm{m} / z$ calcd for $\mathrm{C}_{39} \mathrm{H}_{52} \mathrm{~N}_{2} \mathrm{O}_{3} \mathrm{Si}_{2}+\mathrm{H}^{+}$: $641.3589\left[M+\mathrm{H}^{+}\right]$; found 641.3592 .

$(6 R, 7 S, 8 S, E)-M e t h y l-11-((1 R, 2 S)-2-((S)-2-(($ tert-butyldimethylsilyl)oxy)-2-(1-(2-((tert -butyldiphenyl-silyl)oxy)ethyl)-2-methyl-1H-benzo[d]imidazol-5-yl)ethyl)cyclopropyl)-4, 4,6,8-tetramethyl-5-oxo-7-((triisopropylsilyl)oxy) undec-10-enoate (10A)

A solution of LiHMDS $(618 \mathrm{mg}, 3.969 \mathrm{mmol})$ in THF $(1 \mathrm{~mL})$ was added to a solution of sulfone 9 [34] $(1.07 \mathrm{~g}, 1.680 \mathrm{mmol})$ and aldehyde $8(1.3 \mathrm{~g}, 2.028 \mathrm{mmol})$ in THF $(5 \mathrm{~mL})$ at $-78^{\circ} \mathrm{C}$. The mixture was stirred for $1 \mathrm{~h}$ at $-78{ }^{\circ} \mathrm{C}$ and allowed to warm to rt over a period of $1 \mathrm{~h}$. After quenching the reaction with sat. aq. $\mathrm{NH}_{4} \mathrm{Cl}$, the solution was extracted with EtOAc, and the combined extracts were dried over $\mathrm{MgSO}_{4}$ and concentrated in vacuo. Purification of the residue by FC (Hex/EtOAc/MeOH 1:1:0.01) yielded $1.4 \mathrm{~g}$ of olefin $10 \mathrm{~A}$ as a mixture of isomers (see text).

$R_{\mathrm{f}}=0.88(\mathrm{EtOAc} / \mathrm{MeOH} 20: 1) .[\alpha]_{D}^{20}=-13.3\left(\mathrm{c}=0.8\right.$ in $\left.\mathrm{CHCl}_{3}\right) .{ }^{1} \mathrm{H} \mathrm{NMR}\left(400 \mathrm{MHz}, \mathrm{CDCl}_{3}\right)$ : $\delta=7.60(1 \mathrm{H}, \mathrm{s}), 7.24-7.42(10 \mathrm{H}, \mathrm{m}), 7.10(1 \mathrm{H}, \mathrm{m}), 7.04(1 \mathrm{H}, \mathrm{m}), 5.32(1 \mathrm{H}, \mathrm{m}), 4.95(1 \mathrm{H}, \mathrm{m}), 4.79(1 \mathrm{H}, \mathrm{m})$, $4.22(2 \mathrm{H}, \mathrm{t}, J=5.30 \mathrm{~Hz}), 4.04(1 \mathrm{H}, \mathrm{m}), 3.89(2 \mathrm{H}, \mathrm{t}, J=5.39 \mathrm{~Hz}), 3.65(3 \mathrm{H}, \mathrm{s}), 3.15(1 \mathrm{H}, \mathrm{m}), 2.54(3 \mathrm{H}, \mathrm{s})$, $2.22(2 \mathrm{H}, \mathrm{m}), 1.88-2.06(2 \mathrm{H}, \mathrm{m}), 1.83(2 \mathrm{H}, \mathrm{m}),, 1.74(1 \mathrm{H}, \mathrm{m}), 1.47(1 \mathrm{H}, \mathrm{m}), 1.28(1 \mathrm{H}, \mathrm{m}), 1.19(3 \mathrm{H}, \mathrm{s}), 1.10$ $(28 \mathrm{H}, \mathrm{m}), 0.93(12 \mathrm{H}, \mathrm{br} \mathrm{s}), 0.88(9 \mathrm{H}, \mathrm{s}), 0.82-0.86(1 \mathrm{H}, \mathrm{m}), 0.41(1 \mathrm{H}, \mathrm{t}, J=6.66 \mathrm{~Hz}), 0.03(3 \mathrm{H}, \mathrm{s}),-0.15$ $(3 \mathrm{H}, \mathrm{s}) .{ }^{13} \mathrm{C} \mathrm{NMR}\left(100 \mathrm{MHz}, \mathrm{CDCl}_{3}\right): \delta=217.98,174.14,152.20,142.55,140.00,135.54,135.06,134.48$, 132.67, 129.96, 127.92, 126.34, 120.43, 116.35, 108.77, 77.32, 75.66, 62.14, 51.77, 47.70, 46.28, 45.91, 43.42, $40.23,35.12,34.44,29.89,26.76,26.07,24.80,21.56,19.04,18.61,18.59,18.38,17.83,16.68,16.45,15.97$, 14.15, 13.66, -4.38, -4.76. IR: $v=2926,2856,2362,1741,1697,1521,1462,1430,1389,1360,1254,1112$, $1087,883,836,702 \mathrm{~cm}^{-1}$; HRMS (ESI): $m / z$ calcd for $\mathrm{C}_{62} \mathrm{H}_{98} \mathrm{~N}_{2} \mathrm{O}_{6} \mathrm{Si}_{3}+\mathrm{H}^{+}: 1051.6805\left[M+\mathrm{H}^{+}\right]$; found 1051.6796.

(6R,7S,8S)-Methyl11-((1R,2S)-2-((S)-2-((tert-butyldimethylsilyl)oxy)-2-(1-(2-((tert-butyldiphenylsilyl)oxy)ethyl)-2-methyl-1H-benzo[d]imidazol-5-yl)ethyl)cyclopropyl)-4,4,6,8-tetra -methyl-5-oxo-7-((triisopropylsilyl) oxy) undecanoate (10)

Triethylamine (TEA) $(103 \mu \mathrm{L}, 0.742 \mathrm{mmol})$ was slowly added to a solution of olefin 10A (39 $\mathrm{mg}$, $0.037 \mathrm{mmol})$ and NBSH $(161 \mathrm{mg}, 0.742 \mathrm{mmol})$ in DCM $(2 \mathrm{~mL})$ at $\mathrm{rt}$, and the reaction mixture was stirred overnight. As the reaction was not complete at this point, additional TEA $(200 \mu \mathrm{L}, 1.439 \mathrm{mmol})$ was added over a period of $4 \mathrm{~h}$. After an additional $20 \mathrm{~h}$, more NBSH $(50 \mathrm{mg}, 0.23 \mathrm{mmol})$ and TEA $(100 \mu \mathrm{L}$, $0.72 \mathrm{mmol}$ ) were added, and stirring was continued for $16 \mathrm{~h}$. The solution was then washed with brine, dried over $\mathrm{MgSO}_{4}$, and concentrated in vacuo. Purification of the residue by FC (Hex/EtOAc 2:1) yielded $38.1 \mathrm{mg}$ of saturated ester $\mathbf{1 0}(98 \%)$ as a mixture of isomers (see text). 
$R_{\mathrm{f}}=0.81(\mathrm{EtOAc} / \mathrm{Hex} 1: 1) \cdot[\alpha]_{D}^{20}=-20.6\left(\mathrm{c}=1.0\right.$ in $\left.\mathrm{CHCl}_{3}\right) .{ }^{1} \mathrm{H}$ NMR $\left(400 \mathrm{MHz}, \mathrm{CDCl}_{3}\right): \delta=7.60$ $(1 \mathrm{H}, \mathrm{s}), 7.23-7.43(10 \mathrm{H}, \mathrm{m}), 7.12(1 \mathrm{H}, \mathrm{dd}, J=1.30,8.35 \mathrm{~Hz}), 7.03(1 \mathrm{H}, \mathrm{d}, J=8.35 \mathrm{~Hz}),, 4.77(1 \mathrm{H}, \mathrm{dd}$, $J=5.48,7.32 \mathrm{~Hz}), 4.22(2 \mathrm{H}, \mathrm{t}, J=5.59 \mathrm{~Hz}), 4.03(1 \mathrm{H}, \mathrm{dd}, J=2.58,6.10 \mathrm{~Hz}), 3.89(2 \mathrm{H}, \mathrm{t}, J=5.59 \mathrm{~Hz}), 3.64$ $(3 \mathrm{H}, \mathrm{s}), 3.11(1 \mathrm{H}, \mathrm{q}, J=6.70 \mathrm{~Hz}), 2.54(3 \mathrm{H}, \mathrm{s}), 2.22(2 \mathrm{H}, \mathrm{m}), 1.84(3 \mathrm{H}, \mathrm{m}), 1.49(1 \mathrm{H}, \mathrm{m}), 1.21-1.45(5 \mathrm{H}, \mathrm{m})$, $1.19(3 \mathrm{H}, \mathrm{s}), 1.10(29 \mathrm{H}, \mathrm{m}), 0.94(3 \mathrm{H}, \mathrm{m}), 0.93(9 \mathrm{H}, \mathrm{s}), 0.88(9 \mathrm{H}, \mathrm{s}), 0.49(1 \mathrm{H}, \mathrm{m}), 0.41(1 \mathrm{H}, \mathrm{m}), 0.13(2 \mathrm{H}$, $\mathrm{m}), 0.03(3 \mathrm{H}, \mathrm{s}),-0.14(3 \mathrm{H}, \mathrm{s}) .{ }^{13} \mathrm{C}$ NMR $\left(100 \mathrm{MHz}, \mathrm{CDCl}_{3}\right): \delta=217.94,174.11,152.16,142.53,140.11$, $135.53,134.45,132.67,129.94,127.91,120.39,116.46,108.78,77.04,75.96,62.13,51.73,47.63,46.71,45.89$, $42.78,40.31,34.82,34.55,32.35,29.87,27.91,26.75,26.07,24.88,24.80,19.08,19.03,18.58,18.55,18.40$, 15.93, 15.88, 15.78, 14.15, 13.53, 11.85, -4.36, -4.76. IR: $v=2929,2861,2357,1740,1697,1521,1471$, $1429,1390,1361,1254,1111,1086,1006,883,836,776,740,703,505 \mathrm{~cm}^{-1}$. HRMS (ESI): $\mathrm{m} / \mathrm{z}$ calcd for $\mathrm{C}_{62} \mathrm{H}_{100} \mathrm{~N}_{2} \mathrm{O}_{6} \mathrm{Si}_{3}+\mathrm{H}^{+}: 1053.6962\left[M+\mathrm{H}^{+}\right]$; found 1053.6957.

$(6 R, 7 S, 8 S)-M e t h y l 11-((1 R, 2 S)-2-((S)-2-(1-(2-((t e r t-b u t y l d i p h e n y l s i l y l) o x y) e t h y l)-2-m e t h y l-1 H$ -benzo[d]imidazol-5-yl)-2-hydroxyethyl)cyclopropyl)-4,4,6,8-tetramethyl-5-oxo-7-((triisopropyl -silyl)oxy)undecanoate (11)

Camphorsulfonic acid (CSA) $(0.3 \mathrm{~g}, 1.291 \mathrm{mmol})$ was added to a solution of silyl ether $\mathbf{1 0}(0.38 \mathrm{~g}$, $0.361 \mathrm{mmol})$ in $\mathrm{DCM} / \mathrm{MeOH}$ 1:1 $(16 \mathrm{~mL})$. The solution was stirred overnight at $\mathrm{rt}$ and then neutralized with sat. aq. $\mathrm{NaHCO}_{3}$. The aqueous layer was extracted with DCM, and the combined organic layers were dried over $\mathrm{MgSO}_{4}$ and concentrated in vacuo. Purification of the residue by FC (Hex/EtOAc 9:1) yielded $0.34 \mathrm{~g}$ of partially protected seco acid $\mathbf{1 1}$ (quant) as a mixture of isomers (see text).

$R_{\mathrm{f}}=0.67$ (EtOAc/Hex 9:1). $[\alpha]_{D}^{20}=-14.7\left(\mathrm{c}=1.1\right.$ in $\left.\mathrm{CHCl}_{3}\right) .{ }^{1} \mathrm{H}$ NMR $\left(400 \mathrm{MHz}, \mathrm{CDCl}_{3}\right): \delta=7.65$ $(1 \mathrm{H}, \mathrm{s}), 7.24-7.42(10 \mathrm{H}, \mathrm{m}), 7.17(1 \mathrm{H}, \mathrm{dd}, J=1.41,8.34 \mathrm{~Hz}), 7.04(1 \mathrm{H}, \mathrm{d}, J=8.34 \mathrm{~Hz}), 4.84(1 \mathrm{H}, \mathrm{t}$, $J=6.55 \mathrm{~Hz}), 4.22(2 \mathrm{H}, \mathrm{t}, J=5.66 \mathrm{~Hz}), 4.03(1 \mathrm{H}, \mathrm{dd}, J=2.53,6.10 \mathrm{~Hz}), 3.89(2 \mathrm{H}, \mathrm{t}, J=5.66 \mathrm{~Hz}), 3.64$ $(3 \mathrm{H}, \mathrm{s}), 3.12(1 \mathrm{H}, \mathrm{q}, J=6.62 \mathrm{~Hz}), 2.55(3 \mathrm{H}, \mathrm{s}), 2.22(2 \mathrm{H}, \mathrm{m}), 1.83(3 \mathrm{H}, \mathrm{m}), 1.61(1 \mathrm{H}, \mathrm{m}), 1.48(1 \mathrm{H}, \mathrm{m})$, $1.28(3 \mathrm{H}, \mathrm{m}), 1.19(3 \mathrm{H}, \mathrm{s}), 1.09(30 \mathrm{H}, \mathrm{m}), 0.94(9 \mathrm{H}, \mathrm{s}),, 0.92(3 \mathrm{H}, \mathrm{m}), 0.48(2 \mathrm{H}, \mathrm{m}), 0.17 \mathrm{ppm}(2 \mathrm{H}, \mathrm{m}) .{ }^{13} \mathrm{C}$ NMR $\left(100 \mathrm{MHz}, \mathrm{CDCl}_{3}\right): \delta=217.96,174.14,152.57,142.74,138.92,135.53,134.80,132.65,129.98,127.91$, 120.31, 116.60, 109.25, 77.05, 75.53, 62.02, 51.76, 47.62, 45.88, 44.26, 42.81, 40.27, 34.74, 34.54, 32.34, 29.86, 27.94, 26.77, 24.88, 24.79, 19.06, 19.00, 18.58, 18.55, 15.92, 15.76, 15.64, 14.13, 13.54, 11.51. IR: $v=3229$, 2930, 2865, 2356, 1739, 1696, 1521, 1462, 1429, 1403, 1390, 1111, 1087, 1007, 883, 740, 703, $504 \mathrm{~cm}^{-1}$. HRMS (ESI): $m / z$ calcd for $\mathrm{C}_{56} \mathrm{H}_{86} \mathrm{~N}_{2} \mathrm{O}_{6} \mathrm{Si}_{2}+\mathrm{H}^{+}: 939.6097\left[M+\mathrm{H}^{+}\right]$; found 939.6093.

$(6 R, 7 S, 8 S)-11-((1 R, 2 S)-2-((S)-2-(1-(2-((t e r t-B u t y l d i p h e n y l s i l y l) o x y) e t h y l)-2-m e t h y l-1 H-b e n z o[d]$ imidazol-5-yl)-2-hydroxyethyl)cyclopropyl)-4,4,6,8-tetramethyl-5-oxo-7((triisopropylsilyl)oxy) undecanoic acid (11A)

Lithium hydroxide monohydrate $(223.1 \mathrm{mg}, 5.555 \mathrm{mmol})$ was added to a solution of methyl ester $11(1.04 \mathrm{~g}, 1.111 \mathrm{mmol})$ in $t-\mathrm{BuOH} / \mathrm{H}_{2} \mathrm{O} 4: 1(30 \mathrm{~mL})$. The solution was stirred for $2.5 \mathrm{~h}$ at rt. Water and $1 \mathrm{M} \mathrm{HCI}$ (to $\mathrm{pH}$ ) were then added, and the solution was extracted with DCM. The combined organic extracts were dried over $\mathrm{MgSO}_{4}$ and evaporated in vacuo to furnish obtain $1.000 \mathrm{~g}$ of crude acid 11A (98\%) as a white powder. This material was used in the next step without further purification. $R_{\mathrm{f}}=0.15$ (EtOAc/MeOH 95:5). $[\alpha]_{D}^{20}=+16.4\left(\mathrm{c}=0.7\right.$ in $\left.\mathrm{CHCl}_{3}\right) \cdot{ }^{1} \mathrm{H} \mathrm{NMR}\left(400 \mathrm{MHz}, \mathrm{CDCl}_{3}\right): \delta=7.71$ $(1 \mathrm{H}, \mathrm{s}), 7.25-7.43(10 \mathrm{H}, \mathrm{m}), 7.35(1 \mathrm{H}, \mathrm{m}), 7.14(1 \mathrm{H}, \mathrm{d}, J=8.46 \mathrm{~Hz}), 4.85(1 \mathrm{H}, \mathrm{dd}, J=4.43,10.00 \mathrm{~Hz}), 4.22$ $(2 \mathrm{H}, \mathrm{m}), 4.05(1 \mathrm{H}, \mathrm{dd}, J=2.98,4.59 \mathrm{~Hz}), 3.89(2 \mathrm{H}, \mathrm{t}, J=5.60 \mathrm{~Hz}), 3.18(1 \mathrm{H}, \mathrm{m}), 2.56(3 \mathrm{H}, \mathrm{s}), 2.21-2.36$ $(2 \mathrm{H}, \mathrm{m}), 2.07(1 \mathrm{H}, \mathrm{m}), 1.93(2 \mathrm{H}, \mathrm{m}), 1.67(1 \mathrm{H}, \mathrm{m}), 1.50(3 \mathrm{H}, \mathrm{m}), 1.31(3 \mathrm{H}, \mathrm{s}), 1.25(1 \mathrm{H}, \mathrm{m}), 1.24(1 \mathrm{H}$, $\mathrm{m}), 1.06-1.15(29 \mathrm{H}, \mathrm{m}), 0.95(3 \mathrm{H}, \mathrm{m}), 0.94(9 \mathrm{H}, \mathrm{s}), 0.53(1 \mathrm{H}, \mathrm{m}), 0.10-0.23(2 \mathrm{H}, \mathrm{m}),-0.04(1 \mathrm{H}, \mathrm{m}) .{ }^{13} \mathrm{C}$ NMR $\left(100 \mathrm{MHz}, \mathrm{CDCl}_{3}\right): \delta=219.00,176.43,152.33,139.77,139.20,135.51,134.03,132.53,130.09,127.98$, 119.90, 117.33, 110.31, 75.76, 75.75, 61.93, 47.58, 45.88, 44.04, 41.65, 40.94, 35.32, 34.25, 33.60, 30.46, 27.96, $26.78,24.81,24.36,19.08,18.92,18.52,18.47,16.05,15.00,13.34,13.22,13.13,11.50$. IR: $v=2960,2930$, $2865,2358,2338,1698,1520,1472,1428,1407,1390,1362,1111,1088,883,773,741,703 \mathrm{~cm}^{-1}$. HRMS (ESI): $m / z$ calcd for $\mathrm{C}_{55} \mathrm{H}_{84} \mathrm{~N}_{2} \mathrm{O}_{6} \mathrm{Si}_{2}+\mathrm{H}^{+}: 925.5941\left[M+\mathrm{H}^{+}\right]$; found 925.5937. 


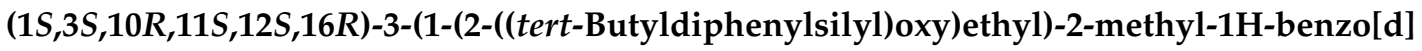
imidazol-5-yl)-8,8,10,12-tetramethyl-11-((triisopropylsilyl)oxy)-4-oxabicyclo[14.1.0] heptadecane-5,9-dione (12)

A solution of acid 11A $(988 \mathrm{mg}, 1.067 \mathrm{mmol})$ in toluene $(20 \mathrm{~mL})$ was slowly added to a solution of TEA $(297 \mu \mathrm{L}, 1.135 \mathrm{mmol}), 2,4,6$ trichlorobenzoyl chloride $(184 \mu \mathrm{L}, 1.174 \mathrm{mmol})$ and DMAP $(170 \mathrm{mg}$, $1.388 \mathrm{mmol})$ in toluene $(500 \mathrm{~mL})$ at $\mathrm{rt}$. The mixture was stirred for $2 \mathrm{~h}$ and the reaction was then quenched with sat. aq. $\mathrm{NaHCO}_{3}$. The solution was extracted with EtOAc, and the combined extracts were dried over $\mathrm{MgSO}_{4}$ and then concentrated in vacuo. Purification of the residue by FC (Hex/EtOAc/MeOH 1:1:0.01) followed by preparative RP-HPLC gave $493 \mathrm{mg}$ of slightly impure macrolactone 12 (51\%). Preparative RP-HPLC: $\mathrm{H}_{2} \mathrm{O}$ with $0.1 \%$ TFA (A) $/ \mathrm{CH}_{3} \mathrm{CN}$ (B). $10 \% \mathrm{~B}$ to $80 \%$ over $20 \mathrm{~min}$, retention time: $8.54 \mathrm{~min}$.

$R_{\mathrm{f}}=0.35$ (EtOAc: Hex 1:1). $[\alpha]_{D}^{20}=-15.7\left(\mathrm{c}=1.0\right.$ in $\left.\mathrm{CHCl}_{3}\right) \cdot{ }^{1} \mathrm{H}$ NMR $\left(400 \mathrm{MHz}, \mathrm{CDCl}_{3}\right): \delta=7.82$ (s, 1H), $7.35(\mathrm{~m}, 6 \mathrm{H}), 7.25(\mathrm{~m}, 6 \mathrm{H}), 5.96(\mathrm{~d}, J=10.1 \mathrm{~Hz}, 1 \mathrm{H}), 4.34(\mathrm{~d}, J=5.2 \mathrm{~Hz}, 2 \mathrm{H}), 4.19(\mathrm{dd}, J=7.3$, $2.2 \mathrm{~Hz}, 1 \mathrm{H}), 4.00(\mathrm{t}, J=4.5 \mathrm{~Hz}, 2 \mathrm{H}), 3.24(\mathrm{p}, J=7.0 \mathrm{~Hz}, 1 \mathrm{H}), 2.79(\mathrm{~s}, 3 \mathrm{H}), 2.35(\mathrm{tdd}, J=27.4,16.2,5.2 \mathrm{~Hz}$, 2H), $2.10(\mathrm{dd}, J=14.5,3.2 \mathrm{~Hz}, 1 \mathrm{H}), 1.95(\mathrm{pd}, J=13.8,5.3 \mathrm{~Hz}, 2 \mathrm{H}), 1.57-1.41(\mathrm{~m}, 4 \mathrm{H}), 1.39(\mathrm{~s}, 3 \mathrm{H})$, $1.37-1.30(\mathrm{~m}, 2 \mathrm{H}), 1.25(\mathrm{~s}, 4 \mathrm{H}), 1.17(\mathrm{~d}, J=7.0 \mathrm{~Hz}, 4 \mathrm{H}), 1.12(\mathrm{~s}, 18 \mathrm{H}), 1.06(\mathrm{~s}, 4 \mathrm{H}), 0.98(\mathrm{~d}, J=6.8 \mathrm{~Hz}$, $3 \mathrm{H}), 0.92(\mathrm{~s}, 9 \mathrm{H}), 0.79-0.70(\mathrm{~m}, 1 \mathrm{H}), 0.57(\mathrm{dt}, J=12.9,4.4 \mathrm{~Hz}, 1 \mathrm{H}), 0.22 \mathrm{ppm}(\mathrm{tt}, J=9.4,4.7 \mathrm{~Hz}, 2 \mathrm{H}) .{ }^{13} \mathrm{C}$ NMR $\left(101 \mathrm{MHz}, \mathrm{CDCl}_{3}\right): \delta=218.62,172.29,151.22,141.20,135.31,131.80,131.56,131.32,130.44,128.11$, 124.67, 112.70, 111.30, 77.48, 76.79, 61.11, 47.35, 46.98, 43.58, 41.96, 39.70, 34.89, 34.47, 30.93, 26.79, 26.51, $25.15,23.98,18.99,18.62,18.58,18.04,17.02,16.75,16.00,13.58,11.80$. IR: $v=2932,2865,2359,2338$, 1731, 1695, 1521, 1463, 1429, 1390, 1255, 1111, 1088, 999, 981, 939, 883, 823, 754, 703, 677, $504 \mathrm{~cm}^{-1}$. HRMS (ESI): $m / z$ calcd for $\mathrm{C}_{55} \mathrm{H}_{82} \mathrm{~N}_{2} \mathrm{O}_{5} \mathrm{Si}_{2}+\mathrm{H}^{+}: 907.5835\left[M+\mathrm{H}^{+}\right]$; found 907.5837.

(1S,3S,10R,11S,12S,16R)-11-Hydroxy-3-(1-(2-hydroxyethyl)-2-methyl-1H-benzo[d]imidazol-5 -yl)-8,8,10,12-tetramethyl-4-oxabicyclo[14.1.0] heptadecane-5,9-dione (1)

Fully protected macrolactone $12(40 \mathrm{mg}, 0.044 \mathrm{mmol})$ was dissolved in THF $(3 \mathrm{~mL})$ and HF.pyridine $(2 \mathrm{~mL})$ was added. The solution was stirred overnight and the reaction then slowly quenched with aq. sat. $\mathrm{NaHCO}_{3}$. The solution was extracted with EtOAc and the combined organic phases were washed with aq. sat. $\mathrm{NaHCO}_{3}$, dried over $\mathrm{MgSO}_{4}$ and concentrated in vacuo. Purification of the residue by $\mathrm{FC}\left(\mathrm{CHCl}_{3} / \mathrm{MeOH} / \mathrm{H}_{2} \mathrm{O} / \mathrm{AcOH}\right.$ 85:13:1.5:0.5) was followed by preparative RP-HPLC purification. RP-HPLC: Injection of a solution of 1 in $\mathrm{MeOH}$ and elution with $0.1 \%$ TFA in $\mathrm{H}_{2} \mathrm{O}$ (A) $/ \mathrm{MeCN}$ (B); $30 \%$ B for $2 \mathrm{~min}$, then gradient to $60 \%$ B over $6 \mathrm{~min}$, and then gradient to $90 \% \mathrm{~B}$ over 3 min. Preparative runs: $30 \%$ B for $2 \mathrm{~min}$ and then to $90 \%$ B over $10 \mathrm{~min}$; retention time $4.67 \mathrm{~min}$ (prep). An amount of $9.11 \mathrm{mg}$ of pure 1 was isolated (33\%) with further mixed fractions.

$R_{\mathrm{f}}=0.37\left(\mathrm{CHCl}_{3} / \mathrm{MeOH} / \mathrm{H}_{2} \mathrm{O} / \mathrm{AcOH} 85: 13: 1.5: 0.5\right) \cdot[\alpha]_{D}^{20}=-15.1(\mathrm{c}=0.5 \mathrm{in} \mathrm{MeOH}) .{ }^{1} \mathrm{H}$ NMR $(500 \mathrm{MHz}, \mathrm{MeOD}): \delta=7.79(\mathrm{~d}, J=8.7 \mathrm{~Hz}, 1 \mathrm{H}), 7.69(\mathrm{~s}, 1 \mathrm{H}), 7.54(\mathrm{dd}, J=8.6,0.7 \mathrm{~Hz}, 1 \mathrm{H}), 6.05(\mathrm{dd}$, $J=11.0,1.0 \mathrm{~Hz}, 1 \mathrm{H}), 4.53(\mathrm{t}, J=5.1 \mathrm{~Hz}, 2 \mathrm{H}), 3.97-3.93(\mathrm{~m}, 2 \mathrm{H}), 3.70(\mathrm{dd}, J=9.9,1.4 \mathrm{~Hz}, 1 \mathrm{H}), 3.29(\mathrm{~d}$, $J=6.7 \mathrm{~Hz}, 1 \mathrm{H}), 2.87(\mathrm{~s}, 3 \mathrm{H}), 2.42-2.32(\mathrm{~m}, 1 \mathrm{H}), 2.24(\mathrm{dd}, J=8.6,6.9 \mathrm{~Hz}, 1 \mathrm{H}), 2.21-2.12(\mathrm{~m}, 1 \mathrm{H}), 2.03-1.94$ $(\mathrm{m}, 1 \mathrm{H}), 1.87(\mathrm{td}, J=14.4,5.2 \mathrm{~Hz}, 1 \mathrm{H}), 1.71(\mathrm{dd}, J=12.8,5.2 \mathrm{~Hz}, 1 \mathrm{H}), 1.57(\mathrm{~d}, J=9.4 \mathrm{~Hz}, 1 \mathrm{H}), 1.48-1.42$ $(\mathrm{m}, 2 \mathrm{H}), 1.35-1.24(\mathrm{~m}, 3 \mathrm{H}), 1.20(\mathrm{~d}, J=6.7 \mathrm{~Hz}, 3 \mathrm{H}), 1.09(\mathrm{dd}, J=16.0,6.9 \mathrm{~Hz}, 1 \mathrm{H}), 1.02(\mathrm{~s}, 3 \mathrm{H}), 0.99(\mathrm{~d}$, $J=6.6 \mathrm{~Hz}, 3 \mathrm{H}), 0.91-0.86(\mathrm{~m}, 1 \mathrm{H}), 0.67-0.61(\mathrm{~m}, 1 \mathrm{H}), 0.27-0.20(\mathrm{~m}, 2 \mathrm{H}) .{ }^{13} \mathrm{C} \mathrm{NMR}\left(100 \mathrm{MHz}, \mathrm{CDCl}_{3}\right)$ : $\delta=219.48,172.13,152.26,140.88,131.37,131.17,124.47,112.29,111.41,76.71,75.83,59.56,47.82,47.55$, $42.31,41.63,36.04,34.37,32.02,30.94,29.53,25.54,25.35,22.78,22.39,18.62,17.23,16.98,14.96,12.03$. IR: $v=3414,2966,2934,2878,2363,1729,1674,1460,1426,1200,1175,1138,975,798,722 \mathrm{~cm}^{-1}$; HRMS (ESI): $m / z$ calcd for $\mathrm{C}_{30} \mathrm{H}_{44} \mathrm{~N}_{2} \mathrm{O}_{5}+\mathrm{H}^{+}: 513.3323\left[M+\mathrm{H}^{+}\right]$; found 513.3323.

(1S,3S,10R,11S,12S,16R)-3-(1-(2-Hydroxyethyl)-2-methyl-1H-benzo[d]imidazol-5-yl)-8,8,10,12 -tetramethyl-11-((triisopropylsilyl)oxy)-4-oxabicyclo[14.1.0] heptadecane-5,9-dione (13)

A solution of dry TASF $(28.2 \mathrm{mg}, 0.102 \mathrm{mmol})$ in DMF $(90 \mu \mathrm{L})$ was added to a solution of dry 12 (93 mg, $0.102 \mathrm{mmol}$, HPLC purified) in DMF ( $5 \mathrm{~mL})$ at $0{ }^{\circ} \mathrm{C}$, and the solution was stirred for $2 \mathrm{~h}$. 
Phosphate buffer $\mathrm{pH} 7$ was then added, and the solution was extracted with $\mathrm{DCM}$, dried over $\mathrm{MgSO}_{4}$ and concentrated in vacuo. Purification of the residue by FC (EtOAc/MeOH 100:1) yielded $70 \mathrm{mg}$ (quant) of alcohol 13 as a colorless oil.

$R_{\mathrm{f}}=0.35(\mathrm{EtOAc} / \mathrm{MeOH} 95: 5) .[\alpha]_{D}^{20}=-21.3\left(\mathrm{c}=0.7\right.$ in $\left.\mathrm{CHCl}_{3}\right) .{ }^{1} \mathrm{H} \mathrm{NMR}\left(400 \mathrm{MHz}, \mathrm{CDCl}_{3}\right)$ : $\delta=7.51(1 \mathrm{H}, \mathrm{s}), 7.21(1 \mathrm{H}, \mathrm{d}, J=8.22 \mathrm{~Hz}), 7.13(1 \mathrm{H}, \mathrm{dd}, J=1.39,8.33 \mathrm{~Hz}), 5.98(1 \mathrm{H}, \mathrm{d}, J=10.20 \mathrm{~Hz}), 4.21$ $(2 \mathrm{H}, \mathrm{t}, J=5.17 \mathrm{~Hz}), 4.16(1 \mathrm{H}, \mathrm{dd}, J=2.14,7.10 \mathrm{~Hz}), 3.98(2 \mathrm{H}, \mathrm{t}, J=5.17 \mathrm{~Hz}), 3.23(1 \mathrm{H}, \mathrm{q}, J=7.00 \mathrm{~Hz})$, $2.47(3 \mathrm{H}, \mathrm{s}), 2.82(2 \mathrm{H}, \mathrm{m}), 2.07(1 \mathrm{H}, \mathrm{m}), 1.92(2 \mathrm{H}, \mathrm{m}), 1.48(3 \mathrm{H}, \mathrm{m}), 1.35(3 \mathrm{H}, \mathrm{s}), 1.26(5 \mathrm{H}, \mathrm{m}), 1.17(3 \mathrm{H}, \mathrm{d}$, $J=7.04 \mathrm{~Hz}), 1.11(21 \mathrm{H}, \mathrm{s}), 1.04(3 \mathrm{H}, \mathrm{s}), 0.98(3 \mathrm{H}, \mathrm{d}, J=6.84 \mathrm{~Hz}), 0.71(1 \mathrm{H}, \mathrm{m}), 0.58(1 \mathrm{H}, \mathrm{m}), 0.20(2 \mathrm{H}, \mathrm{m})$. ${ }^{13} \mathrm{C}$ NMR $\left(100 \mathrm{MHz}, \mathrm{CDCl}_{3}\right): \delta=218.28,172.26,153.05,142.16,136.05,134.68,120.90,115.93,109.27$, 77.65, 77.38, 60.78, 47.43, 46.54, 43.52, 42.17, 39.69, 34.86, 34.50, 31.06, 26.59, 25.49, 23.83, 18.68, 18.68, 18.61, 18.05, 17.27, 16.71, 16.06, 13.91, 13.57, 11.41. IR: $v=3197,2962,2942,2866,2356,2338,1731,1696$, $1520,1465,1406,1389,1254,1122,1067,1041,999,982,883,756,677 \mathrm{~cm}^{-1}$; HRMS (ESI): $\mathrm{m} / \mathrm{z}$ calcd for $\mathrm{C}_{39} \mathrm{H}_{64} \mathrm{~N}_{2} \mathrm{O}_{5} \mathrm{Si}+\mathrm{H}^{+}: 669.4657\left[\mathrm{M}+\mathrm{H}^{+}\right]$; found 669.4649 .

S-(2-(5-((1S,3S,10R,11S,12S,16R)-11-Hydroxy-8,8,10,12-tetramethyl-5,9-dioxo-4-oxabicyclo[14.1.0] heptadecan-3-yl)-2-methyl-1H-benzo[d]imidazol-1-yl)ethyl) ethanethioate (14)

DEAD ( $35 \mu \mathrm{L}, 0.219 \mathrm{mmol}$ ) was added to a solution of $\mathrm{PPh}_{3}(57.6 \mathrm{mg}, 0.219 \mathrm{mmol})$ in $\mathrm{Et}_{2} \mathrm{O}(4 \mathrm{~mL})$ at $0{ }^{\circ} \mathrm{C}$, and the mixture was stirred for $1 \mathrm{~h}$ at that temperature. Thioacetic acid $(17 \mu \mathrm{L}, 0.241)$ was then added followed by slow addition of a solution of $\mathbf{1 3}(70 \mathrm{mg}, 0.104 \mathrm{mmol})$ in $\mathrm{Et}_{2} \mathrm{O}(5 \mathrm{~mL})$. The cooling bath was removed, and the solution was stirred at rt for $2.5 \mathrm{~h}$. It was then washed with brine, and the aqueous solution was back-extracted with EtOAc. The combined organic extracts were dried over $\mathrm{MgSO}_{4}$ and concentrated in vacuo. Purification of the residue by FC (EtOAc/MeOH 100:1) gave $130 \mathrm{mg}$ of protected thioacetate contaminated with triphenylphosphine oxide; $5 \mathrm{mg}$ of $\mathbf{1 3}$ were recovered. The protected thioacetate was dissolved in THF $(5 \mathrm{~mL})$ and a total of $5 \mathrm{~mL}$ of pyridine and $9 \mathrm{~mL}$ of HF py were added in portions over a period of $53 \mathrm{~h} . \mathrm{NaHCO}_{3}$ was then carefully added to the mixture to reach $\mathrm{pH} 7-8$, and the solution was extracted with EtOAc. The combined organic extracts were dried over $\mathrm{MgSO}_{4}$ and concentrated in vacuo. Purification of the residue by $\mathrm{FC}\left(\mathrm{CHCl}_{3} / \mathrm{MeOH} / \mathrm{H}_{2} \mathrm{O} / \mathrm{AcOH}\right.$ 90:10:1:0.5 and $\mathrm{CHCl}_{3} / \mathrm{MeOH} / \mathrm{AcOH}$ 95:4.5:0.5) yielded $52 \mathrm{mg}$ (87\% over 2 steps) of thioacetate 14 as a colorless oil. Ten milligrams of this material were purified by preparative RP-HPLC: Injection of a solution of 1 in $\mathrm{MeOH}$ and elution with $0.1 \%$ TFA in $\mathrm{H}_{2} \mathrm{O}(\mathrm{A}) / \mathrm{CH}_{3} \mathrm{CN}(\mathrm{B}) ; 30 \%$ B for 2 min, then to $60 \%$ B over $6 \mathrm{~min}$, and then to $90 \%$ B over $3 \mathrm{~min}$. Preparative HPLC: $30 \%$ B for $2 \mathrm{~min}$ and then to $70 \%$ over $10 \mathrm{~min}$. Retention time 6.60 (prep). An amount of $2.42 \mathrm{mg}$ of pure 14 was recovered after HPLC (22\% yield based on 13 ).

$R_{\mathrm{f}}=0.07\left(\mathrm{CHCl}_{3} / \mathrm{MeOH} / \mathrm{AcOH} 95: 4.5: 0.5\right) \cdot[\alpha]_{D}^{20}=-27.1\left(\mathrm{c}=0.9\right.$ in $\left.\mathrm{CHCl}_{3}\right) .{ }^{1} \mathrm{H} \mathrm{NMR}(400 \mathrm{MHz}$, $\left.\mathrm{CDCl}_{3}\right): \delta=7.62(1 \mathrm{H}, \mathrm{s}), 7.36(1 \mathrm{H}, \mathrm{d}, J=8.26 \mathrm{~Hz}), 7.20(1 \mathrm{H}, \mathrm{dd}, J=1.39,8.26 \mathrm{~Hz}), 6.00(1 \mathrm{H}, \mathrm{dd}, J=1.62$, $10.19 \mathrm{~Hz}), 4.22(2 \mathrm{H}, \mathrm{m}), 3.78(1 \mathrm{H}, \mathrm{dd}, J=3.09,6.72 \mathrm{~Hz}), 3.29(1 \mathrm{H}, \mathrm{q}, J=6.72 \mathrm{~Hz}), 3.16(2 \mathrm{H}, \mathrm{m}), 2.65(3 \mathrm{H}$, s), $2.38(3 \mathrm{H}, \mathrm{s}), 2.17-2.34(2 \mathrm{H}, \mathrm{m}), 2.11(1 \mathrm{H}, \mathrm{m}), 1.87-2.02(2 \mathrm{H}, \mathrm{m}), 1.54(5 \mathrm{H}, \mathrm{m}), 1.34(3 \mathrm{H}, \mathrm{s}), 1.25(2 \mathrm{H}$, m), $1.18(3 \mathrm{H}, \mathrm{d}, J=6.79 \mathrm{~Hz}), 1.02(3 \mathrm{H}, \mathrm{s}), 1.00(3 \mathrm{H}, \mathrm{d}, J=6.79 \mathrm{~Hz}), 0.89(1 \mathrm{H}, \mathrm{m}), 0.64(1 \mathrm{H}, \mathrm{m}), 0.56(1 \mathrm{H}$, m), $0.18 \mathrm{ppm}(2 \mathrm{H}, \mathrm{m}) .{ }^{13} \mathrm{C} \mathrm{NMR}\left(100 \mathrm{MHz}, \mathrm{CDCl}_{3}\right): \delta=219.18,195.28,172.02,152.20,142.01,136.43$, 134.11, 121.33, 116.05, 109.1, 77.51, 76.07, 47.88, 43.16, 42.32, 41.93, 36.11, 34.44, 34.41, 31.11, 30.79, 29.86, 28.24, 25.69, 25.55, 22.26, 18.53, 17.33, 17.28, 15.21, 13.63, 11.01. IR: $v=3267,2962,2930,2856,2363,1725$, $1691,1521,1458,1402,1252,1133,1039,975,754,623 \mathrm{~cm}^{-1}$; HRMS (ESI): $\mathrm{m} / z$ calcd for $\mathrm{C}_{32} \mathrm{H}_{46} \mathrm{~N}_{2} \mathrm{O}_{5} \mathrm{~S}+$ $\mathrm{H}^{+}: 571.3200\left[\mathrm{M}+\mathrm{H}^{+}\right]$; found 571.3195 .

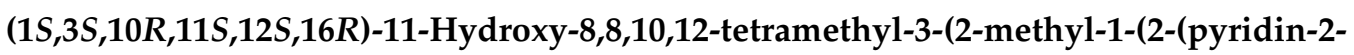
yldisulfanyl)ethyl)-1H-benzo[d]imidazol-5-yl)-4-oxabicyclo[14.1.0] heptadecane-5,9-dione (15)

$\mathrm{K}_{2} \mathrm{CO}_{3}(5 \mathrm{mg})$ was added to a solution of $14(11 \mathrm{mg}, 0.019 \mathrm{mmol})$ and 2,2'-dipyridyl disulfide $(5.1 \mathrm{mg}, 0.023 \mathrm{mmol})$ in dry $\mathrm{MeOH}(2 \mathrm{~mL})$, and the mixture was stirred at $\mathrm{rt}$ for $30 \mathrm{~min}$. Brine was added and the solution was extracted with EtOAc. The combined organic extracts were dried over $\mathrm{MgSO}_{4}$ and concentrated. Purification of the residue by FC yielded $9.7 \mathrm{mg}(79 \%)$ of activated disulfide $\mathbf{1 5 .}$ 
$R_{\mathrm{f}}=0.76(\mathrm{EtOAc} / \mathrm{MeOH} 9: 1) .[\alpha]_{D}^{20}=-45.3\left(\mathrm{c}=0.4\right.$ in $\left.\mathrm{CHCl}_{3}\right) .{ }^{1} \mathrm{H} \mathrm{NMR}\left(400 \mathrm{MHz}, \mathrm{CDCl}_{3}\right)$ : $\delta=8.50(1 \mathrm{H}, \mathrm{dq}, J=0.90,4.02 \mathrm{~Hz}) 7.60(3 \mathrm{H}, \mathrm{m}), 7.22(1 \mathrm{H}, \mathrm{d}, J=8.21 \mathrm{~Hz}), 7.14(2 \mathrm{H}, \mathrm{m}), 4.98(1 \mathrm{H}, \mathrm{dd}$, $J=1.72,10.18 \mathrm{~Hz}), 4.46(2 \mathrm{H}, \mathrm{t}, J=7.31 \mathrm{~Hz}), 3.77(1 \mathrm{H}, \mathrm{dd}, J=2.95,6.66 \mathrm{~Hz}), 3.28(1 \mathrm{H}, \mathrm{q}, J=6.76 \mathrm{~Hz})$, $3.12(2 \mathrm{H}, \mathrm{t}, J=7.33 \mathrm{~Hz}), 2.60(3 \mathrm{H}, \mathrm{s}), 2.13-2.38(2 \mathrm{H}, \mathrm{m}),, 2.07(1 \mathrm{H}, \mathrm{m}), 1.80-2.01(2 \mathrm{H}, \mathrm{m}), 1.54(5 \mathrm{H}, \mathrm{m})$, $1.33(3 \mathrm{H}, \mathrm{s}), 1.27(2 \mathrm{H}, \mathrm{m}), 1.18(3 \mathrm{H}, \mathrm{d}, J=6.76 \mathrm{~Hz}), 1.02(3 \mathrm{H}, \mathrm{s}), 1.00(3 \mathrm{H}, \mathrm{d}, J=6.85 \mathrm{~Hz}), 0.87(1 \mathrm{H}, \mathrm{m})$, $0.56-0.64(2 \mathrm{H}, \mathrm{m}), 0.18(2 \mathrm{H}, \mathrm{m}) .{ }^{13} \mathrm{C}$ NMR $\left(100 \mathrm{MHz}, \mathrm{CDCl}_{3}\right): \delta=219.13,171.99,158.78,152.24,150.30$, 142.73, 137.36, 136.23, 134.38, 121.56, 121.14, 120.68, 116.28, 108.83, 77.57, 76.07, 47.89, 42.94, 42.32, 42.01, $37.12,36.13,34.47,34.43,31.13,29.90,25.75,25.59,22.29,18.56,17.38,17.28,15.19,14.26,11.06$. IR: $v=3269,2926,2855,2017,1727,1690,1574,1521,1447,1418,1401,1250,975,760 \mathrm{~cm}^{-1}$; HRMS (ESI): $m / z$ calcd for $\mathrm{C}_{35} \mathrm{H}_{47} \mathrm{~N}_{3} \mathrm{O}_{4} \mathrm{~S}_{2}+\mathrm{H}^{+}$: $638.3081\left[M+\mathrm{H}^{+}\right]$; found 638.3075 .

(S)-2-((S)-1-((6R,9S,12S,15S,18S,24S,27S)-12-((1H-imidazol-4-yl)methyl)-15-((1H-indol-3-yl) methyl)-6-amino-1-(5-((1S,3S,10R,11S,12S,16R)-11-hydroxy-8,8,10,12-tetramethyl-5,9-dioxo-4oxabicyclo[14.1.0] heptadecan-3-yl)-2-methyl-1H-benzo[d]imidazol-1-yl)-9,18,24-tris(4-hydroxy -benzyl)-27-((R)-1-hydroxyethyl)-7,10,13,16,19,22,25-heptaoxo-3,4-dithia-8,11,14,17,20,23,26 -heptaazaoctacosan-28-oyl)pyrrolidine-2-carboxamido)-N1-((S)-4-amino-1-(((S)-1-(((2S,3S)1-amino-3-methyl-1-oxopentan-2-yl)amino)-3-methyl-1-oxobutan -2-yl)amino)-1,4-dioxobutan-2-yl)pentanediamide (4)

Cys-GE11 (11 mg, $0.0067 \mathrm{mmol})$ and 15 (4.3 mg, $0.0067 \mathrm{mmol})$ were dissolved in $\mathrm{MeOH}$, and the solution was stirred at $\mathrm{rt}$ for $2 \mathrm{~h}$. Evaporation of the solvent and purification of the residue by preparative HPLC yielded $2.45 \mathrm{mg}$ (15\%) of conjugate 4. Analytical RP-HPLC (C18): $\mathrm{H}_{2} \mathrm{O}$ with $0.1 \%$ TFA (A) $/ \mathrm{H}_{2} \mathrm{O} / \mathrm{CH}_{3} \mathrm{CN} 8 / 2$ with $0.05 \%$ TFA (B); gradient from $5 \% \mathrm{~B}$ to $80 \%$ B over $30 \mathrm{~min}$. Preparative RP-HPLC: Gradient from 5\% B to $70 \%$ B over 30 min. $[\alpha]_{D}^{20}=-1.5$ (c = 0.2 in MeOH). IR: $v=3853,3821$, 3751, 3735, 3710, 3690, 3676, 3670, 3649, 3629, 3587, 3567, 2361, 2334, 1684, 1559, 1540, 1507, 1457, 1208, 1186, 1138, 801, $725 \mathrm{~cm}^{-1}$; HRMS (ESI): $\mathrm{m} / z$ calcd for $\mathrm{C}_{108} \mathrm{H}_{145} \mathrm{~N}_{21} \mathrm{O}_{23} \mathrm{~S}_{2}+\mathrm{H}^{+}: 2169.0341\left[M+\mathrm{H}^{+}\right]$; found 2169.0355 (Figure 4).

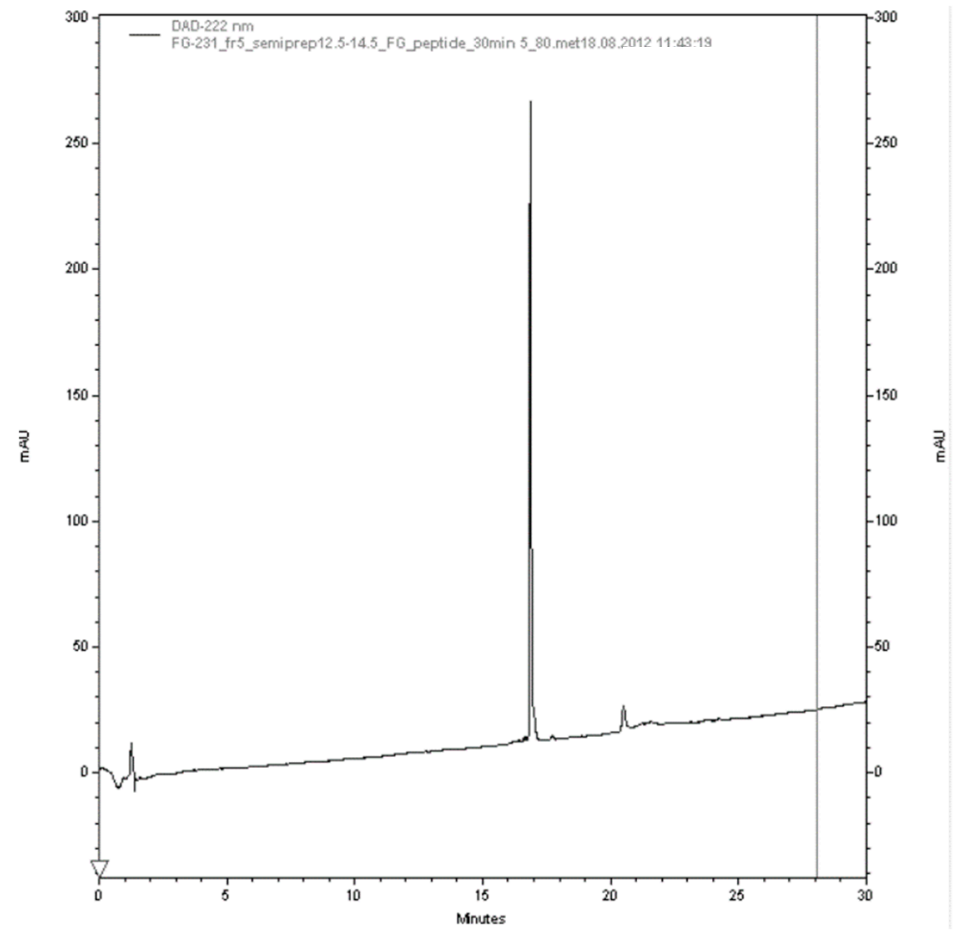

Figure 4. Analytical RP-HPLC trace of 4 after preparative RP-HPLC. 
Dimer of $(1 S, 3 S, 10 R, 11 S, 12 S, 16 R)-11-h y d r o x y-3-(1-(2-m e r c a p t o e t h y l)-2-m e t h y l-1 H-b e n z o[d]$ imidazol-5-yl)-8,8,10,12-tetramethyl-4-oxabicyclo[14.1.0]heptadecane-5,9-dione (16)

$\mathrm{K}_{2} \mathrm{CO}_{3}(5 \mathrm{mg})$ was added to a solution of $14(13 \mathrm{mg}, 0.023 \mathrm{mmol})$ in dry $\mathrm{MeOH}(2 \mathrm{~mL})$, and the mixture was stirred at $\mathrm{rt}$ for $20 \mathrm{~min}$. Brine was added and the solution was extracted with EtOAc. The combined organic extracts were dried over $\mathrm{MgSO}_{4}$ and concentrated. The crude residue was purified by preparative HPLC. Although care was taken throughout the purification process to exclude air as much as possible, the material recovered after lyophilization contained disulfide $\mathbf{1 6}$ as the major component. Repurification of this material gave $3.51 \mathrm{mg}$ (24\%) of pure disulfide 16. Preparative RP-HPLC: $\mathrm{H}_{2} \mathrm{O}$ with $0.1 \%$ TFA $/ \mathrm{CH}_{3} \mathrm{CN} ; 30 \% \mathrm{~B}$ for $2 \mathrm{~min}$ and then to $90 \% \mathrm{~B}$ over $10 \mathrm{~min}$. Retention time $5.44 \mathrm{~min} / 6.21 \mathrm{~min}$ for monomer/dimer (prep).

$$
R_{\mathrm{f}}=0.76(\mathrm{EtOAc} / \mathrm{MeOH} 9: 1) \cdot[\alpha]_{D}^{20}=-3.3(\mathrm{c}=0.1 \mathrm{in} \mathrm{MeOH}) .{ }^{1} \mathrm{H} \mathrm{NMR}(500 \mathrm{MHz}, \mathrm{MeOD}): \delta=7.82
$$
$(\mathrm{d}, J=8.6 \mathrm{~Hz}, 2 \mathrm{H}), 7.70(\mathrm{~s}, 2 \mathrm{H}), 7.57(\mathrm{dd}, J=8.7,1.3 \mathrm{~Hz}, 2 \mathrm{H}), 6.04(\mathrm{~d}, J=10.5 \mathrm{~Hz}, 2 \mathrm{H}), 4.73(\mathrm{t}, J=6.5 \mathrm{~Hz}$, $4 \mathrm{H}), 3.70(\mathrm{dd}, J=9.7,0.9 \mathrm{~Hz}, 2 \mathrm{H}), 3.26(\mathrm{t}, J=6.3 \mathrm{~Hz}, 4 \mathrm{H}), 2.88(\mathrm{~s}, 6 \mathrm{H}), 2.35(\mathrm{ddd}, J=16.2,12.9,4.7 \mathrm{~Hz}$, $2 \mathrm{H}), 2.22(\mathrm{~d}, J=14.5 \mathrm{~Hz}, 2 \mathrm{H}), 2.19-2.11(\mathrm{~m}, 2 \mathrm{H}), 1.91(\mathrm{dtd}, J=53.2,13.6,4.7 \mathrm{~Hz}, 5 \mathrm{H}), 1.75-1.63(\mathrm{~m}, 2 \mathrm{H})$, $1.60-1.51(\mathrm{~m}, 3 \mathrm{H}), 1.48-1.41(\mathrm{~m}, 4 \mathrm{H}), 1.40(\mathrm{~s}, 6 \mathrm{H}), 1.30-1.23(\mathrm{~m}, 3 \mathrm{H}), 1.19(\mathrm{~d}, J=6.7 \mathrm{~Hz}, 6 \mathrm{H}), 1.13-1.04$ $(\mathrm{m}, 3 \mathrm{H}), 1.00(\mathrm{~s}, 6 \mathrm{H}), 0.98(\mathrm{~d}, J=6.6 \mathrm{~Hz}, 6 \mathrm{H}), 0.92-0.82(\mathrm{~m}, 2 \mathrm{H}), 0.63(\mathrm{tt}, J=12.7,6.4 \mathrm{~Hz}, 2 \mathrm{H}), 0.26-0.19$ $(\mathrm{m}, 4 \mathrm{H}) .{ }^{13} \mathrm{C}$ NMR $(126 \mathrm{MHz}, \mathrm{MeOD}) \delta=218.32,172.15,152.13,140.96,131.64,123.91,119.94,112.34$, $111.38,77.27,77.16,47.02,43.94,43.56,41.44,35.60,35.13,34.29,34.01,30.29,28.02,25.30,24.68,21.72$, 18.12, 17.79, 17.22, 15.98, 10.82, 9.44. IR: $v=2927,2852,2363,2343,2018,1715,1684,1199,1138,974,725$ $\mathrm{cm}^{-1}$; HRMS (ESI): $m / z$ calcd for $\mathrm{C}_{60} \mathrm{H}_{86} \mathrm{~N}_{4} \mathrm{O}_{8} \mathrm{~S}_{2}+\mathrm{H}^{+}: 1055.5960\left[M+\mathrm{H}^{+}\right]$; found 1055.5958 .

\subsection{Glutathione Cleavage Assay}

For cytoplasm-like conditions, $100 \mu \mathrm{L}$ of a $173 \mu \mathrm{M}$ solution of conjugate 4 in degassed $100 \mathrm{mM}$ phosphate buffer $\mathrm{pH} 7.4$ were diluted with $400 \mu \mathrm{L}$ of a degassed phosphate buffer and $500 \mu \mathrm{L}$ of $20 \mathrm{mM}$ glutathione in $100 \mathrm{mM}$ phosphate buffer $\mathrm{pH}$ 7.4. Aliquots of $80 \mu \mathrm{L}$ were removed at predefined time points, and the reaction was quenched with one volume of $10 \%$ metaphosphoric acid, giving a $\mathrm{pH}$ of 1 approximately. Fifty microliters of this solution were analyzed by analytical RP-HPLC. The same protocol was used for cleavage under endosome-like conditions, except that the glutathione solution was prepared in a $100 \mathrm{mM}$ acetate buffer at $\mathrm{pH} 4.8$, and the same buffer was also used to dilute the conjugate solution in a $100 \mathrm{mM}$ phosphate buffer at $\mathrm{pH}$ 7.4. The final $\mathrm{pH}$ of the cleavage solution was 4.9 .

Analytical RP-HPLC: $\mathrm{H}_{2} \mathrm{O}$ with $0.1 \%$ TFA (A)/acetonitrile/water $8 / 2$ with $0.05 \%$ TFA (B). Linear gradient from $5 \% \mathrm{~B}$ to $80 \% \mathrm{~B}$ over $30 \mathrm{~min}$. The percentage of remaining conjugate in the solutions was plotted against time (Figure 3). Analysis of the cleavage solutions by LC/MS provided information of the fractions of the various components in the redox mixture. As an example, Figure S2 shows the product distribution after $5 \mathrm{~min}$ of reaction time under endosome-like conditions.

\subsection{Determination of Microtubule Binding Constants}

Purified calf-brain tubulin and chemicals were obtained as previously described [50]. Stabilized, moderately crosslinked microtubules were prepared as reported in [42]. Binding constants of azathilones to stabilized microtubules were measured as previously described by Buey et al. [41]. For details of the experimental procedures and Flutax-2 displacement curves cf. Section SI.3 of the Supplementary Materials.

\subsection{Antiproliferative Activity}

Experiments were performed in RPMI (SW480 cells) or DMEM (HEK293 and A431 cells) medium (Gibco) supplemented with $2 \mathrm{mM}$ glutamine, $10 \%$ fetal bovine serum, $100 \mathrm{IU} / \mathrm{mL}$ penicillin, $100 \mu \mathrm{g} / \mathrm{mL}$ streptomycin, and $1 \mu \mathrm{g} / \mathrm{mL}$ amphotericin B (all from Sigma) at $37^{\circ} \mathrm{C}$ and $5 \% \mathrm{CO}_{2}$. Cells were seeded into 96-well microtiter plates and compounds were added in DMSO in serial dilutions in triplicate. 
The final DMSO (dimethylsulfoxide) concentration was $0.1 \%$. After $72 \mathrm{~h}$, a WST-1 reagent [43] was added and the absorption was measured at $450 \mathrm{~nm}$ with a plate reader after $30 \mathrm{~min}$ to $4 \mathrm{~h}$. The percentage of viable cells was calculated based on vehicle-treated cells and was plotted in GraphPadPrism. At least three independent experiments were performed.

A431 cells were obtained from CLS. The other cell lines were available in the laboratory. WST-1 was purchased from Roche.

For inhibition curves cf. Section SI.5 of the Supplementary Materials.

\section{Conclusions}

We have successfully prepared a disulfide-linked conjugate between a novel epothilone analog and the (purported) EGFR-binding peptide GE11, and we have determined its microtubule-binding affinity and its in vitro antiproliferative activity against EGFR-overexpressing cells and cells being devoid of EGFR. While the conjugate had been designed to specifically target EGFR-overexpressing cells, its in vitro antiproliferative activity was found to be independent of EGFR expression status, at least for the limited number of cell lines evaluated. While our study has been limited in scope, in combination with other data in the literature, our findings could suggest that GE11 does not represent an effective targeting moiety for EGFR-overexpressing tumor cells, and even less so in combination with a disulfide linker (contrary to our original working hypothesis).

Independent of the uncertainties surrounding the activity of the specific epothilone conjugate 4 that we have investigated in this study, our work does demonstrate that the new epothilone analog 1 can serve as highly active template for the construction of targeted prodrugs. The compound exhibits $\mathrm{nM}$ antiproliferative activity against a variety of cell lines and offers a readily accessible, sterically unencumbered primary hydroxyl group for chemical manipulation; the requisite partially protected precursor for these manipulations (i.e., intermediate 13) can be prepared on a scale that allows the production of reasonable amounts of prodrugs for subsequent biochemical, cell biological, and pharmacological studies. The preparation of such prodrugs will be the subject of future studies in our laboratory.

Supplementary Materials: Supplementary materials can be found at http:/ /www.mdpi.com/1422-0067/20/5/1113/ s1.

Author Contributions: F.Z.G., K-H.A., and J.F.D. conceived the research and designed the experiments; F.Z.G., A.C., I.B., and M.R.-H. performed the experiments; F.Z.G., K-H.A., and J.F.D. analyzed the data; F.Z.G. and K-H.A. wrote the paper.

Funding: We are indebted to the Swiss National Science Foundation (F.G.Z.; project number 205320-117594) and the ETH Zürich for generous financial support. This work was also supported by Ministerio de Economia y Competitividad grant BFU2016-75319-R to FDP (AEI/FEDER, UE). We thank Ganadería Fernando Díaz for the supply of calf brains. The authors acknowledge networking contributions by the COST Action CM1407 "Challenging organic syntheses inspired by nature - from natural products chemistry to drug discovery" and the COST action CM1470.

Acknowledgments: We are indebted to Bernhard Pfeiffer (ETHZ) for NMR support and to Xiangyang Zhang, Louis Bertschi, Rolf Häfliger, and Oswald Greter (ETHZ) for HRMS spectra. We thank Dario Neri, ETH Zürich, and Jürg Gertsch, University of Bern, and their respective groups for support with cell culture experiments and Gregor Fuhrman (ETHZ) for LC-MS of the GE11 conjugate. We are grateful to Stefan Vetterli and Raphael Schiess for generously providing substantial quantities of sulfone 9 .

Conflicts of Interest: The authors declare no conflict of interest.

\section{References and Note}

1. Todd, A.; Groundwater, P.W.; Gill, J.H. Anticancer Therapeutics: From Drug Discovery to Clinical Applications; Wiley-Blackwell: Hoboken, NJ, USA, 2018; pp. 211-232.

2. LaPointe, N.E.; Morfini, G.; Brady, S.T.; Feinstein, S.C.; Wilson, L.; Jordan, M.A. Effects of eribulin, vincristine, paclitaxel and ixabepilone on fast axonal transport and kinesin-1 driven microtubule gliding: Implications for chemotherapy-induced peripheral neuropathy. NeuroToxicology 2013, 37, 231-239. [CrossRef] [PubMed] 
3. Chari, R.V.; Miller, M.L.; Widdison, W.C. Antibody-drug conjugates: An emerging concept in cancer therapy. Angew. Chem. Int. Ed. 2014, 53, 3796-3827. [CrossRef] [PubMed]

4. Nasiri, H.; Valedkarimi, Z.; Aghebati-Maleki, L.; Majidi, J. Antibody-drug conjugates: Promising and efficient tools for targeted cancer therapy. J. Cell. Physiol. 2018, 233, 6441-6457. [CrossRef] [PubMed]

5. Zhao, N.; Qin, Y.; Liu, H.; Cheng, Z. Tumor-Targeting Peptides: Ligands for Molecular Imaging and Therapy. Anti-Cancer Agents Med. Chem. 2018, 18, 74-86. [CrossRef] [PubMed]

6. Srinivasarao, M.; Galliford, C.V.; Low, P.S. Principles in the design of ligand-targeted cancer therapeutics and imaging agents. Nat. Rev. Drug Discov. 2015, 14, 203-219. [CrossRef] [PubMed]

7. Casi, G.; Neri, D. Antibody-Drug Conjugates and Small Molecule-Drug Conjugates: Opportunities and Challenges for the Development of Selective Anticancer Cytotoxic Agents. J. Med. Chem. 2015, 58, 8751-8761. [CrossRef] [PubMed]

8. Zhuang, C.; Guan, X.; Ma, H.; Cong, H.; Zhang, W.; Miao, Z. Small molecule-drug conjugates: A novel strategy for cancer-targeted treatment. Eur. J. Med. Chem. 2019, 163, 883-895. [CrossRef] [PubMed]

9. Frigerio, M.; Kyle, A.F. The Chemical Design and Synthesis of Linkers Used in Antibody Drug Conjugates. Curr. Top. Med. Chem. 2017, 17, 3393-3424. [CrossRef] [PubMed]

10. Menchon, G.; Prota, A.E.; Lucena-Agell, D.; Bucher, P.; Jansen, R.; Irschik, H.; Müller, R.; Paterson, I.; Díaz, J.F.; Altmann, K.-H.; et al. A fluorescence anisotropy assay to discover and characterize ligands targeting the maytansine site of tubulin. Nat. Commun. 2018, 9, 2106. [CrossRef] [PubMed]

11. Gerth, K.; Bedorf, N.; Höfle, G.; Irschik, H.; Reichenbach, H. Epothilons A and B: Antifungal and Cytotoxic Compounds from Sorangium cellulosum (Myxobacteria). Production, Physico-chemical and Biological Properties. J. Antibiot. 1996, 49, 560-563. [CrossRef] [PubMed]

12. Bollag, D.M.; McQueney, P.A.; Zhu, J.; Hensens, O.; Koupal, L.; Liesch, J.; Goetz, M.; Lazarides, E.; Woods, C.M. Epothilones, a new class of microtubule-stabilizing agents with a Taxol-like mechanism of action. Cancer Res. 1995, 55, 2325-2333. [PubMed]

13. Kowalski, R.J.; Giannakakou, P.; Hamel, E. Activities of the microtubule-stabilizing agents epothilones A and B with purified tubulin and in cells resistant to paclitaxel (Taxol). J. Biol. Chem. 1997, 272, 2534-2541. [CrossRef] [PubMed]

14. Altmann, K.-H.; Wartmann, M.; O’Reilly, T. Epothilones and related structures-A new class of microtubule inhibitors with potent in vivo antitumor activity. Biochim. Biophys. Acta 2000, 1470, M79-M91. [CrossRef]

15. O’Reilly, T.; Wartmann, M.; Brueggen, J.; Allegrini, P.R.; Flörsheimer, A.; Maira, M.; McSheehy, P.M.J. Pharmacokinetic profile of the microtubule stabilizer patupilone in tumor-bearing rodents and comparison of anti-cancer activity with other MTS in vitro and in vivo. Cancer Chemother. Pharmacol. 2008, 62, 1045-1054. [CrossRef] [PubMed]

16. O’Reilly, T.; McSheehy, P.M.J.; Wenger, F.; Hattenberger, M.; Muller, M.; Vaxelaire, J.; Altmann, K.-H.; Wartmann, M. EPO906 (epothilone B) is active in vivo against experimental prostate tumors. Prostate 2005, 65, 231-240. [CrossRef] [PubMed]

17. Altmann, K.-H.; Pfeiffer, B.; Arseniyadis, S.; Pratt, B.A.; Nicolaou, K.C. The chemistry and biology of epothilones-The wheel keeps turning. ChemMedChem 2007, 2, 397-423. [CrossRef] [PubMed]

18. The Epothilones: An Outstanding Family of Anti-Tumor Agents (Progress Chem. Org. Nat. Prod. 90); Kinghorn, A.D., Falk, H., Kobayashi, J., Eds.; Springer: Wienna, Austria; New York, NY, USA, 2009; ISBN 978-3-211-78207-1.

19. Lechleider, R.J.; Kaminskas, E.; Jiang, X.; Aziz, R.; Bullock, J.; Kasliwal, R.; Harapanhalli, R.; Pope, S.; Sridhara, R.; Leighton, J.; et al. Ixabepilone in Combination with Capecitabine and as Monotherapy for Treatment of Advanced Breast Cancer Refractory to Previous Chemotherapies. Clin. Cancer Res. 2008, 14, 4378-4384. [CrossRef] [PubMed]

20. Barten, D.M.; Fanara, P.; Andorfer, C.; Hoque, N.; Wong, P.Y.A.; Husted, K.H.; Cadelina, G.W.; DeCarr, L.B.; Yang, L.; Liu, V.; et al. Hyperdynamic microtubules, cognitive deficits, and pathology are improved in tau transgenic mice with low doses of the microtubule-stabilizing agent BMS-241027. J. Neurosci. 2012, 32, 7137-7145. [CrossRef] [PubMed]

21. Zhang, P.; Sun, T.; Zhang, Q.; Yuan, Z.; Jiang, Z.; Wang, X.J.; Cui, S.; Teng, Y.; Hu, X.-C.; Yang, J.; et al. Utidelone plus capecitabine versus capecitabine alone for heavily pretreated metastatic breast cancer refractory to anthracyclines and taxanes: A multicentre, open-label, superiority, phase 3, randomised controlled trial. Lancet Oncol. 2017, 18, 371-383. [CrossRef] 
22. UTD1 (utidelone, depoxythilone) is being developed by Beijing Biostar Technologies (see ref. 21 and the English translation of the company webpage: https://translate.google.ch/translate?hl=de\&sl=zh-CN\& $\mathrm{u}=\mathrm{http}: / /$ www.biostar-pharm.com/\&prev=search). According to a SciFinder search, the company has filed two patent applications on epothilone-type compounds (Tang, L.; Qiu, R. De-epoxidized epothilone derivative preparation, preparation of same and use thereof in the treatment of tumour. CN 107041886, 6 February, 2016; WO 2017133706, 6 February, 2017.) While both of these applications are in Chinese, it is clear that the major claims are for Epo D or a closely related compound. We thus consider it likely that UTD1 is a close analog of Epo D, if not Epo D itself.

23. Vlahov, I.R.; Vite, G.D.; Kleindl, P.J.; Wang, Y.; Santhapuram, H.K.R.; You, F.; Howard, S.J.; Kim, S.-H.; Lee, F.F.Y.; Leamon, C.P. Regioselective synthesis of folate receptor-targeted agents derived from epothilone analogs and folic acid. Bioorg. Med. Chem. Lett. 2010, 20, 4578-4581. [CrossRef] [PubMed]

24. Kuzniewski, C.N.; Gertsch, J.; Wartmann, M.; Altmann, K.-H. Total Synthesis of Hypermodified Epothilone Analogs with Potent in vitro Antitumor Activity. Org. Lett. 2008, 10, 1183-1186. [CrossRef] [PubMed]

25. Gaugaz, F.Z.; Redondo-Horcajo, M.; Barasoain, I.; Díaz, J.F.; Cobos-Correa, A.; Kaufmann, M.; Altmann, K.-H. The Impact of Cyclopropane Configuration on the Biological Activity of Cyclopropyl-Epothilones. ChemMedChem 2014, 9, 2227-2232. [CrossRef] [PubMed]

26. Li, Z.; Zhao, R.; Wu, X.; Sun, Y.; Yao, M.; Li, J.; Xu, Y.; Gu, J. Identification and characterization of a novel peptide ligand of epidermal growth factor receptor for targeted delivery of therapeutics. FASEB J. 2005, 19, 1978-1985. [CrossRef] [PubMed]

27. Ullrich, A.; Coussens, L.; Hayflick, J.S.; Dull, T.J.; Gray, A.; Tam, A.W.; Lee, J.; Yarden, Y.; Libermann, T.A.; Schlessinger, J.; et al. Human epidermal growth factor receptor cDNA sequence and aberrant expression of the amplified gene in A431 epidermoid carcinoma cells. Nature 1984, 309, 418-425. [CrossRef] [PubMed]

28. Mitsudomi, T.; Yatabe, Y. Epidermal growth factor receptor in relation to tumor development: EGFR gene and cancer. FEBS J. 2010, 277, 301-308. [CrossRef] [PubMed]

29. Song, S.; Liu, D.; Peng, J.; Sun, Y.; Li, Z.; Gu, J.-R.; Xu, Y. Peptide ligand-mediated liposome distribution and targeting to EGFR expressing tumor in vivo. Int. J. Pharm. 2008, 363, 155-161. [CrossRef] [PubMed]

30. Du, C.; Qi, Y.; Zhang, Y.; Wang, Y.; Zhao, X.; Min, H.; Han, X.; Lang, J.; Qin, H.; Shi, Q.; et al. Epidermal Growth Factor Receptor-Targeting Peptide Nanoparticles Simultaneously Deliver Gemcitabine and Olaparib to Treat Pancreatic Cancer with Breast Cancer 2 (BRCA2) Mutation. ACS Nano 2018, 12, 10785-10796. [CrossRef] [PubMed]

31. Freeman, H.; Srinivasan, S.; Das, D.; Stayton, P.S.; Convertine, A.J. Fully synthetic macromolecular prodrug chemotherapeutics with EGFR targeting and controlled camptothecin release kinetics. Polym. Chem. 2018, 9 , 5224-5233. [CrossRef]

32. Chen, C.-J.; Chan, C.-H.; Lin, K.-L.; Chen, J.-H.; Tseng, C.-H.; Wang, P.-Y.; Chien, C.-Y.; Yu, H.-M.; Lin, W.-J. ${ }^{68}$ Ga-labelled NOTA-RGD-GE11 peptide for dual integrin and EGFR-targeted tumour imaging. Nucl. Med. Biol. 2019. published online. [CrossRef] [PubMed]

33. Charette, A.B.; Juteau, H.; Lebel, H.; Molinaro, C. Enantioselective Cyclopropanation of Allylic Alcohols with Dioxaborolane Ligands: Scope and Synthetic Applications. J. Am. Chem. Soc. 1998, 120, 11943-11952. [CrossRef]

34. Kuzniewski, C.N.; Glauser, S.; et al. Synthesis, Profiling and Bioactive Conformation of trans-Cyclopropyl Epothilones. Manuscript submitted.

35. Cusack, N.J.; Reese, C.B.; Risius, A.C.; Roozpeikar, B. 2,4,6-Tri-isopropylbenzenesulphonyl hydrazide: A convenient source of di-imide. Tetrahedron 1976, 32, 2157-2162. [CrossRef]

36. Haukaas, M.; O’Doherty, G.A. Enantioselective synthesis of 2-deoxy-and 2,3-dideoxyhexoses. Org. Lett. 2002, 4, 1771-1774. [CrossRef] [PubMed]

37. Inanaga, J.; Hirata, K.; Saeki, H.; Katsuki, T.; Yamaguchi, M. A Rapid Esterification by Means of Mixed Anhydride and Its Application to Large-ring Lactonization. Bull. Chem. Soc. Jpn. 1979, 52, 1989-1993. [CrossRef]

38. Scheidt, K.A.; Chen, H.; Follows, B.C.; Chemler, S.R.; Coffey, D.S.; Roush, W.R. Tris(dimethylamino)sulfonium Difluorotrimethylsilicate, a Mild Reagent for the Removal of Silicon Protecting Groups. J. Org. Chem. 1998, 63, 6436-6437. [CrossRef] 
39. Zhang, F.; Wang, S.; Yin, L.; Yang, Y.; Guan, Y.; Wang, W.; Xu, H.; Tao, N. Quantification of Epidermal Growth Factor Receptor Expression Level and Binding Kinetics on Cell Surfaces by Surface Plasmon Resonance Imaging. Anal. Chem. 2015, 87, 9960-9965. [CrossRef] [PubMed]

40. Shigeta, K.; Hayashida, T.; Hoshino, Y.; Okabayashi, K.; Endo, T.; Ishii, Y.; Hasegawa, H.; Kitagawa, Y. Expression of Epidermal Growth Factor Receptor Detected by Cetuximab Indicates Its Efficacy to Inhibit In Vitro and In Vivo Proliferation of Colorectal Cancer Cells. PLoS ONE 2013, 8, e66302. [CrossRef] [PubMed]

41. Wu, C.; Belenda, C.; Leroux, J.-C.; Gauthier, M.A. Interplay of Chemical Microenvironment and Redox Environment on Thiol-Disulfide Exchange Kinetics. Chem. Eur. J. 2011, 17, 10064-10070. [CrossRef] [PubMed]

42. Buey, R.M.; Díaz, J.F.; Andreu, J.M.; O’Brate, A.; Giannakakou, P.; Nicolaou, K.C.; Sasmal, P.K.; Ritzen, A.; Namoto, K. Interaction of Epothilone Analogs with the Paclitaxel Binding Site: Relationship between Binding Affinity, Microtubule Stabilization, and Cytotoxicity. Chem. Biol. 2004, 11, 225-236. [PubMed]

43. Díaz, J.F.; Strobe, R.; Engelborghs, Y.; Souto, A.A.; Andreu, J.M. Molecular Recognition of Taxol by Microtubules: Kinetics and thermodynamics of binding of fluorescent taxol derivatives to an exposed site. J. Biol. Chem. 2000, 275, 26265-26276. [CrossRef] [PubMed]

44. Feyen, F.; Cachoux, F.; Gertsch, J.; Wartmann, M.; Altmann, K.-H. Epothilones as Lead Structures for the Synthesis-Based Discovery of New Chemotypes for Microtubule Stabilization. Acc. Chem. Res. 2008, 41, 21-31. [CrossRef] [PubMed]

45. Jantsch, A.; Nieto, L.; Gertsch, J.; Rodríguez-Salarichs, J.; Matesanz, R.; Jiménez-Barbero, J.; Díaz, J.F.; Canales, Á.; Altmann, K.-H. Synthesis, Biological Profiling and Determination of the Tubulin-Bound Conformation of 12-Aza-Epothilones (Azathilones). Molecules 2016, 21, 1010. [CrossRef] [PubMed]

46. Austin, C.D.; Wen, X.; Gazzard, L.; Nelson, C.; Scheller, R.H.; Scales, S.J. Oxidizing potential of endosomes and lysosomes limits intracellular cleavage of disulfide-based antibody-drug conjugates. Proc. Natl. Acad. Sci. USA 2005, 102, 17987-17992. [CrossRef] [PubMed]

47. Abourbeh, G.; Shir, A.; Mishani, E.; Ogris, M.; Rödl, W.; Wagner, E.; Levitzki, A. PolyIC GE11 polyplex inhibits EGFR-overexpressing tumors. IUBMB Life 2012, 64, 324-330. [CrossRef] [PubMed]

48. Kuo, W.-T.; Lin, W.-C.; Chang, K.-C.; Huang, J.-Y.; Yen, K.-C.; Young, I.-C.; Sun, Y.-J.; Young, I.-C.; Lin, F.-H. Quantitative Analysis of Ligand-EGFR Interactions: A Platform for Screening Targeting Molecules. PLoS ONE 2015, 10, e0116610. [CrossRef] [PubMed]

49. Striese, F.; Sihver, W.; Gao, F.; Bergmann, R.; Walther, M.; Pietzsch, J.; Steinbach, J.; Pietzsch, H.-J. Exploring pitfalls of ${ }^{64} \mathrm{Cu}$-labeled EGFR-targeting peptide GE11 as a potential PET tracer. Amino Acids 2018, 50, 1415-1431. [CrossRef] [PubMed]

50. Díaz, J.F.; Andreu, J.M. Assembly of purified GDP-tubulin into microtubules induced by taxol and taxotere: Reversibility, ligand stoichiometry, and competition. Biochemistry 1993, 32, 2747-2755. [CrossRef] [PubMed] 